\title{
Evaluating seasonal sea-ice cover over the Southern Ocean from the Last Glacial Maximum
}

\author{
Ryan A. Green ${ }^{1,2,3}$, Laurie Menviel ${ }^{1,2}$, Katrin J. Meissner ${ }^{1,2}$, and Xavier Crosta ${ }^{4}$ \\ ${ }^{1}$ Climate Change Research Centre, University of New South Wales, Sydney, Australia \\ ${ }^{2}$ ARC Centre of Excellence for Climate System Science, Sydney, Australia \\ ${ }^{3}$ Earth and Planetary Sciences, University of California, Santa Cruz, USA \\ ${ }^{4}$ Université de Bordeaux EPOC, UMR 5805, Pessac, France
}

Correspondence: Ryan A. Green (rygreen@ucsc.edu)

\begin{abstract}
Sea-ice cover over the Southern Ocean responds to and impacts Southern Ocean dynamics and, thus, mid to high latitude climate in the Southern Hemisphere. In addition, sea-ice cover can significantly modulate the carbon exchange between the atmosphere and the ocean. As climate models are the only tool available to project future climate changes, it is important to assess their performance in simulating past changes. The Last Glacial Maximum (LGM, 21,000 years ago) represents an interesting target as it is a relatively well documented period with climatic conditions and a carbon cycle very different from pre-industrial conditions. Here, we study the changes in seasonal Antarctic sea-ice cover as simulated in numerical PMIP3 and LOVECLIM simulations of the LGM, and their relationship with windstress and ocean temperature. Simulations and paleo-proxy records suggest a fairly well constrained glacial winter sea-ice edge at $51.5^{\circ} \mathrm{S}$ (1 sigma range: $50^{\circ}-55.5^{\circ} \mathrm{S}$ ). Simulated glacial summer sea-ice cover however differs widely between models, ranging from almost no sea ice to a sea-ice edge reaching $55.5^{\circ} \mathrm{S}$. The austral summer multi-model mean sea-ice edge lies at $\sim 60.5^{\circ} \mathrm{S}$ (1 sigma range: $57.5^{\circ}-70.5^{\circ} \mathrm{S}$ ). Given the lack of strong constraints on the summer sea-ice edge based on sea-ice proxy records, we extend our model-data comparison to summer sea-surface temperature. Our analysis suggests that the multi-model mean summer sea ice provides a reasonable, albeit upper end, estimate of the austral summer sea-ice edge allowing us to conclude that the multi-model mean of austral summer and winter sea-ice cover seem to provide good estimates of LGM conditions. Using these best estimates, we find that there was a larger sea-ice seasonality during the LGM compared to the present day.
\end{abstract}

\section{Introduction}

Antarctic sea ice plays an important role in the Earth's climate system, affecting marine productivity, air-sea gas exchange, ocean circulation, heat transport, surface albedo, carbon uptake and deep-water formation. Specifically, it can both impact and respond to changes in Southern Ocean circulation, and it has been shown to impact the concentration of atmospheric $\mathrm{CO}_{2}$ on glacial-interglacial timescales (e.g., Ferrari et al., 2014).

While Arctic sea-ice cover has significantly decreased over the last few decades, Antarctic sea-ice cover has been more dynamic. Antarctic sea-ice cover slowly expanded from the late 1970's until 2014, before sharply decreasing (Parkinson, 2019; Cavalieri and Parkinson, 2012; Wang et al., 2019). This decline in sea-ice cover is thought to be due to an intense 
https://doi.org/10.5194/cp-2020-155

Preprint. Discussion started: 22 December 2020

(c) Author(s) 2020. CC BY 4.0 License.

\section{(c) $\underset{\mathrm{BY}}{\mathrm{BV}}$}

southern annual mode (SAM) negative phase as changes in Ekman transport lead to higher sea-surface temperatures (SST) around Antarctica (Doddridge and Marshall, 2017). Due to continued anthropogenic emissions of carbon dioxide, the southern hemispheric westerly winds are projected to strengthen and to shift towards positive phases of the SAM (Zheng et al., 2013), impacting Southern Ocean circulation and sea-ice cover further (Mayewski et al., 2017). Given that the Southern Ocean has accounted for $43 \% \pm 3 \%$ of anthropogenic $\mathrm{CO}_{2}$ uptake between 1870 and 1995 (Sabine et al., 2004; Frölicher et al., 2015; Mikaloff-Fletcher et al., 2006; Landschützer et al., 2015), it is crucial to better understand the processes that impact Antarctic sea-ice cover. Understanding past changes in sea ice and their natural drivers, at different timescales and under different boundary conditions, will therefore allow us to better project future sea ice changes.

The Last Glacial Maximum (LGM, 19,000 to 23,000 years ago) featured large continental ice-sheets over North America and Eurasia (e.g., Carlson and Winsor, 2012; Clark et al., 2009), as well as an extended Antarctic ice-sheet (Bentley et al., 2014), and an atmospheric $\mathrm{CO}_{2}$ concentration of $\sim 185 \mathrm{ppm}$ (Marcott et al., 2014). Despite significant progress in characterizing the LGM sea-surface conditions (e.g., Waelbroeck et al., 2009), oceanic circulation (e.g., Howe et al., 2016; Lynch-Stieglitz et al., 2007; Menviel et al., 2017; Skinner et al., 2017), and mechanisms leading to a lower atmospheric $\mathrm{CO}_{2}$ concentration (e.g., Kohfeld and Chase, 2017), significant uncertainties remain.

For the first time in 1981, Antarctic sea ice at the LGM was reconstructed using proxy data (CLIMAP-Project-Members, 1981). Since then, there has been significant progress and the most recent reconstruction mainly uses diatom assemblages and statistical methods to reconstruct summer and winter sea-ice extent during the LGM (Gersonde et al., 2005; Benz et al., 2016). Reconstructions suggest a significantly extended Antarctic sea-ice cover in austral winter, reaching as far north as $\sim 48-49^{\circ} \mathrm{S}$ in the Atlantic and Indian sectors of the Southern Ocean (Gersonde et al., 2005; Allen et al., 2011; Ferry et al., 2015; Nair et al., 2019; Xiao et al., 2016), but only a limited amount of sea-ice cover for austral summer (Gersonde et al., 2005; Benz et al., 2016). However, there is an obvious lack of adequate records implying that summer LGM sea-ice cover is poorly constrained.

Though paleo-proxy records are an invaluable tool to reconstruct the climate system, they are sometimes scarce or completely absent over entire regions. Climate models can help fill these gaps, as they provide a full 3-dimensional and dynamically consistent representation of the climate system. The Paleoclimate Intercomparison Project (PMIP) has been set up to evaluate and compare model performances across consistent boundary conditions (Kageyama et al., 2017). Results from the PMIP phase 4 are currently being released (Kageyama et al., 2020), while phases 1-3 are currently available to the public (https://pmip3.lsce.ipsl.fr).

PMIP2 LGM simulations suggested that simulated LGM Antarctic sea-ice cover did not reflect the zonal variability nor the seasonality seen in proxy reconstructions (Roche et al., 2012). PMIP3 LGM simulations have also been analyzed, with results highlighting large inter-model differences in annual-mean Antarctic sea-ice area and the impact of these differences on ocean stratification and circulation (Marzocchi and Jansen, 2017).

No study has yet looked in detail into the seasonal changes in Antarctic sea-ice cover as simulated by PMIP3 models under LGM boundary conditions. Here, we provide an overview of austral summer and austral winter conditions, corresponding to minimum and maximum LGM Antarctic sea-ice cover as simulated by PMIP3 models and an additional Earth system model 
https://doi.org/10.5194/cp-2020-155

Preprint. Discussion started: 22 December 2020

(c) Author(s) 2020. CC BY 4.0 License.

\section{(c) (i)}

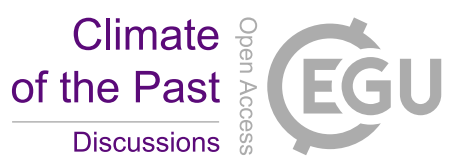

(LOVECLIM). We analyze the processes that lead to these differences, focusing on the simulated sea-ice cover during austral summer and compare the results to the latest available paleo-proxy data.

\section{Materials and Methods}

\subsection{LGM numerical simulations and proxy data}

In this study, we include all PMIP3 LGM simulations which provide sea-ice variables in the PMIP3 database (Table 1). Each LGM simulation follows the PMIP3 protocol (https://wiki.lsce.ipsl.fr/pmip3/doku.php/pmip3:design:21k:final), with the models being forced with orbital parameters set to values corresponding to 21,000 years ago, concentrations of atmospheric greenhouse gases of $185 \mathrm{ppm}$ for $\mathrm{CO}_{2}, 350 \mathrm{ppb}$ for $\mathrm{CH}_{4}$, and $200 \mathrm{ppb}$ for $\mathrm{N}_{2} \mathrm{O}$ with LGM Northern Hemispheric ice-sheet geometry and albedo (Abe-Ouchi et al., 2015).

In total, data from eight models were obtained (11 different simulations, Table 1). When two different simulations were available for the same model (CCSM4, GISS-E2-R, and MPI-ESM-P), data was averaged to yield one output per model in order to prevent overweighting any single model. We also include two additional LGM numerical simulations performed with an Earth system model of intermediate complexity, LOVECLIM (Goosse et al., 2010). Similar to the PMIP3 models, these simulations were forced with appropriate LGM orbital parameters, Northern Hemispheric ice-sheet topography and albedo, and greenhouse gases (Menviel et al., 2017). LOVECLIM consists of an ocean general circulation model, a dynamicthermodynamic sea-ice model, coupled to a quasi-geostrophic atmospheric model, and a dynamic vegetation model (Goosse et al., 2010). These simulations were performed to study the impact of changes in oceanic circulation on the carbon cycle, and thus also allow us to estimate the impact of changes in oceanic circulation on Southern Ocean properties. Two simulations are used: i) one with a weaker North Atlantic Deep Water (NADW) formation at the LGM than pre-industrial, obtained by adding $0.05 \mathrm{~Sv}$ of freshwater to the North Atlantic (simulation V3LNAw in Menviel et al. 2017, here referred to as LOVECLIM1), ii) one with weaker LGM NADW and Antarctic Bottom Water (AABW) formation, obtained by adding $0.05 \mathrm{~Sv}$ of freshwater to the North Atlantic, $0.1 \mathrm{~Sv}$ to the Southern Ocean, as well as by weakening the southern hemispheric westerlies by $20 \%$ (simulation V3LNAwSOwSHWw in Menviel et al. 2017, here referred to as LOVECLIM2). To ease the comparison, we interpolated each model to a $1^{\circ} \mathrm{x} 1^{\circ}$ grid with the software CDO (Climate Data Operators, Schulzweida et al. 2014).

The numerical simulations are compared to a compilation of 149 proxy records covering the LGM (See Table S1 in the Supplement, Allen et al. 2011; Benz et al. 2016; Ferry et al. 2015; Xiao et al. 2016; Gersonde et al. 2005; Ghadi et al. 2020; Nair et al. 2019). Of these, quantitative sea-surface temperature was reconstructed in 138 locations, proxy for winter sea-ice presence or concentration was available in 149 locations and proxy for summer sea-ice presence was available in 132 locations. Sea-surface temperatures were derived from diatom-based transfer functions (Crosta et al., 1998; Esper and Gersonde, 2014a) while winter and summer sea-ice extent were derived either from the relative abundance of sea-ice indicator diatoms, respectively the Fragilariopsis curta group and F. obliquecostata (Gersonde et al., 2005), or diatom-based transfer functions whenever possible (Crosta et al., 1998; Esper et al., 2014b). Relative abundances of the indicator diatoms greater than $3 \%$ are thought to indicate the common presence of sea ice (average sea-ice extent) while relative abundances between 2 and 
Table 1. Models and experiments used in this study. The last column indicates the name of the simulation(s). AO: coupled Atmosphere-Ocean GCMs (vegetation is prescribed), AOV: coupled Atmosphere-Ocean-Vegetation GCMs (vegetation is computed by the model). QAOV: quasi geostrophic atmospheric model coupled to ocean GCM with dynamic vegetation model.

\begin{tabular}{|c|c|c|c|c|c|}
\hline Model Name & Modelling Center & Type & Grid & Reference(s) & Ensembles \\
\hline CNRM & $\begin{array}{l}\text { Centre National de la Recherche } \\
\text { Météorologique (CNRM) \& Centre } \\
\text { Européen de Recherche et de For- } \\
\text { mation Avancée en Calcul Scien- } \\
\text { tifique (CERFACS), France }\end{array}$ & $\mathrm{AO}$ & $\begin{array}{l}\text { Atm: } 256 \times 128 \times L 31 \\
\text { Ocean: } 362 \times 292 \times L 42\end{array}$ & $\begin{array}{l}\text { (Voldoire et al., } \\
\text { 2013) }\end{array}$ & rli1p1 \\
\hline GISS-E2-R & $\begin{array}{l}\text { Goddard Institute for Space Studies } \\
\text { (GISS), USA }\end{array}$ & $\mathrm{AO}$ & $\begin{array}{l}\text { Atm: } 144 \times 90 x L 40 \\
\text { Ocean: 288x180xL32 }\end{array}$ & $\begin{array}{l}\text { (Schmidt et al., } \\
2014,2011)\end{array}$ & $\begin{array}{l}\text { rlilp150 } \\
\text { r1ilp151 }\end{array}$ \\
\hline IPSL-CM5A-LR & $\begin{array}{l}\text { Institut Pierre Simon Laplace } \\
\text { (IPSL), France }\end{array}$ & $\mathrm{AOV}$ & $\begin{array}{l}\text { Atm: } \quad 96 \times 96 \times 239 \\
\text { Ocean: } 182 \times 149 \times L 31\end{array}$ & $\begin{array}{l}\text { (Dufresne } \\
\text { et al., 2013; } \\
\text { Kageyama } \\
\text { et al., 2013) }\end{array}$ & r1ilp1 \\
\hline MIROC-ESM-P & $\begin{array}{l}\text { Japan Agency for Marine-Earth } \\
\text { Science and Technology, Atmo- } \\
\text { sphere and Ocean Research Insti- } \\
\text { tute (The University of Tokyo), and } \\
\text { National Institute for Environmen- } \\
\text { tal Studies }\end{array}$ & $\mathrm{AOV}$ & $\begin{array}{l}\text { Atm: } 128 \times 64 x L 80 \\
\text { Ocean: } 256 x 192 x L 44\end{array}$ & $\begin{array}{l}\text { (Sueyoshi et al., } \\
\text { 2013; Watanabe } \\
\text { et al., 2011) }\end{array}$ & rlilp1 \\
\hline MPI-ESM-P & $\begin{array}{l}\text { Max Planck Institut für Meteorolo- } \\
\text { gie (MPI), Germany }\end{array}$ & $\mathrm{AO}$ & $\begin{array}{l}\text { Atm: } \quad 196 \times 98 \times L 47 \\
\text { Ocean: } 256 \times 220 \times L 40\end{array}$ & $\begin{array}{l}\text { (Giorgetta } \\
\text { et al., 2013; } \\
\text { Klockmann } \\
\text { et al., 2016) }\end{array}$ & r1i1p1 r1ilp2 \\
\hline MRI-CGCM3 & $\begin{array}{l}\text { Meteorological Research Institute } \\
\text { (MRI), Japan }\end{array}$ & $\mathrm{AO}$ & $\begin{array}{l}\text { Atm: } 20 \times 160 \times L 48 \\
\text { Ocean: } 364 \times 368 \times L 51\end{array}$ & $\begin{array}{l}\text { (Yukimoto } \\
\text { et al., 2012) }\end{array}$ & r1ilp1 \\
\hline FGOALS-G2 & $\begin{array}{l}\text { Institute of Atmospheric Physics, } \\
\text { Chinese Academy of Sciences } \\
\text { (LASGIAP) }\end{array}$ & $\mathrm{AOV}$ & $\begin{array}{l}\text { Atm: } 128 \times 60 x L 26 \\
\text { Ocean: 360x180xL30 }\end{array}$ & $\begin{array}{l}\text { (Li et al., 2013; } \\
\text { Zheng and Yu, } \\
\text { 2013) }\end{array}$ & r1ilp1 \\
\hline CCSM4 & $\begin{array}{l}\text { National Center for Atmospheric } \\
\text { Research (NCAR), USA }\end{array}$ & $\mathrm{AO}$ & $\begin{array}{l}\text { Atm: } 288 \times 192 \times L 26 \\
\text { Ocean: } 320 \times 384 \times L 60\end{array}$ & $\begin{array}{l}\text { (Gent et al., } \\
2011 \text {; Brady } \\
\text { et al., 2013) }\end{array}$ & r1i1p1 r2i1p1 \\
\hline LOVECLIM 1.2 & $\begin{array}{l}\text { Université Catholique de Louvain, } \\
\text { Belgium, UNSW, Australia }\end{array}$ & QAOV & $\begin{array}{l}\text { Atm: } \quad 64 \times 32 \times L 3 \\
\text { Ocean: } 120 x 60 x L 20\end{array}$ & $\begin{array}{l}\text { (Goosse et al., } \\
\text { 2010; Menviel } \\
\text { et al., 2017) }\end{array}$ & $\begin{array}{l}\text { LOVECLIM1 } \\
\text { LOVECLIM2 }\end{array}$ \\
\hline
\end{tabular}


Table 2. Austral winter and austral summer months used for each model. The contour colour for each model corresponds to Figures 1 and 2.

\begin{tabular}{cccc}
\hline Model name & Austral winter & Austral summer & Contour color \\
\hline CNRM & September-October & February-March & Black \\
GISS-E2-R & September-October & February-March & Dashed black \\
IPSL-CM5A-LR & August-September & February-March & Green \\
MIROC-ESM-P & September-October & February-March & Blue \\
MPI-ESM-P & September-October & February-March & Dashed pink \\
MRI-CGCM3 & September-October & February-March & Cyan \\
FGOALS-G2 & September-October & March-April & Red \\
LOVECLIM1 & July-August & January-February & Dashed cyan \\
LOVECLIM2 & August-September & February-March & Dashed green \\
CCSM4 & September-October & March-April & Pink \\
\hline
\end{tabular}

$3 \%$ suggest the episodic presence of sea ice (maximum sea-ice extent). In this study, we characterize the relative abundance of $>3 \%$ as evidence of paleo sea ice and the relative abundance between 2 and $3 \%$ as evidence for possible paleo sea ice. Quantitative values were considered to indicate the presence of winter sea ice when they were above the root mean square error of prediction (RMSEP) on the validation models, generally around 10\% for winter sea ice (Crosta et al., 1998; Esper et al., 2014b). Quantitative values were always below the RMSEP of 10\% for summer sea ice on the validation model. When calculating the proxy sea-ice extent, a South Pole stereographic projection is used to calculate surfaces. For consistency, a South Pole sterographic projection is also used for the models in Figures 1 and 3.

\subsection{Definitions of sea-ice edge, extent, seasonality, and regions}

We analyze the climatology of Antarctic sea-ice extent, since we do not take polynyas into account, and define the two months of maximum and minimum sea ice for each individual model (Table 2). These two months of maximum and minimum sea ice are used consistently throughout the study and will hereafter be referred to as each model's austral "winter" and "summer", respectively. We also analyze simulated sea ice within specific regions which we refer to by the ocean basin the region lies in: Atlantic Sector, Pacific Sector, and Indian Sector.

The sea-ice edge is defined as the 15\% sea-ice concentration isoline. For model simulations that do not reach $15 \%$ of sea-ice concentration in certain regions of the Southern Ocean, we average only over the regions with sufficient sea-ice cover and classify the resulting latitude as the sea-ice edge for the model. For model simulations that do not reach a minimum of $15 \%$ sea-ice concentration in any region, we define the latitude of their sea-ice edge as the latitude of the Antarctic coast. It is important to note that although a model's sea-ice edge gives insight into its sea-ice characteristics, it is not always an accurate 
https://doi.org/10.5194/cp-2020-155

Preprint. Discussion started: 22 December 2020

(c) Author(s) 2020. CC BY 4.0 License.

(c) (i)

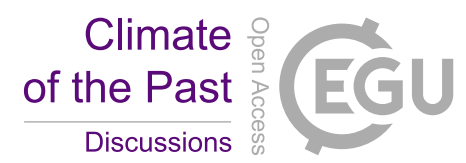

representation of how much total sea ice a model simulates. Due to this, we also calculated the total sea-ice extent for each model (using a cut-off limit of $15 \%$ in concentration). The proxy

\section{Results}

\subsection{Overview of results and comparison to paleo-proxy records}

Figure 1 shows the austral winter and austral summer mean LGM sea-ice extent as simulated by each of the eight PMIP3 models considered here, the LOVECLIM LGM simulations, as well as the multi-model mean and one standard deviation. For comparison, available paleo-proxy records are overlaid for austral winter and austral summer. The simulated annual mean LGM sea-ice extent is shown in Figure S1.
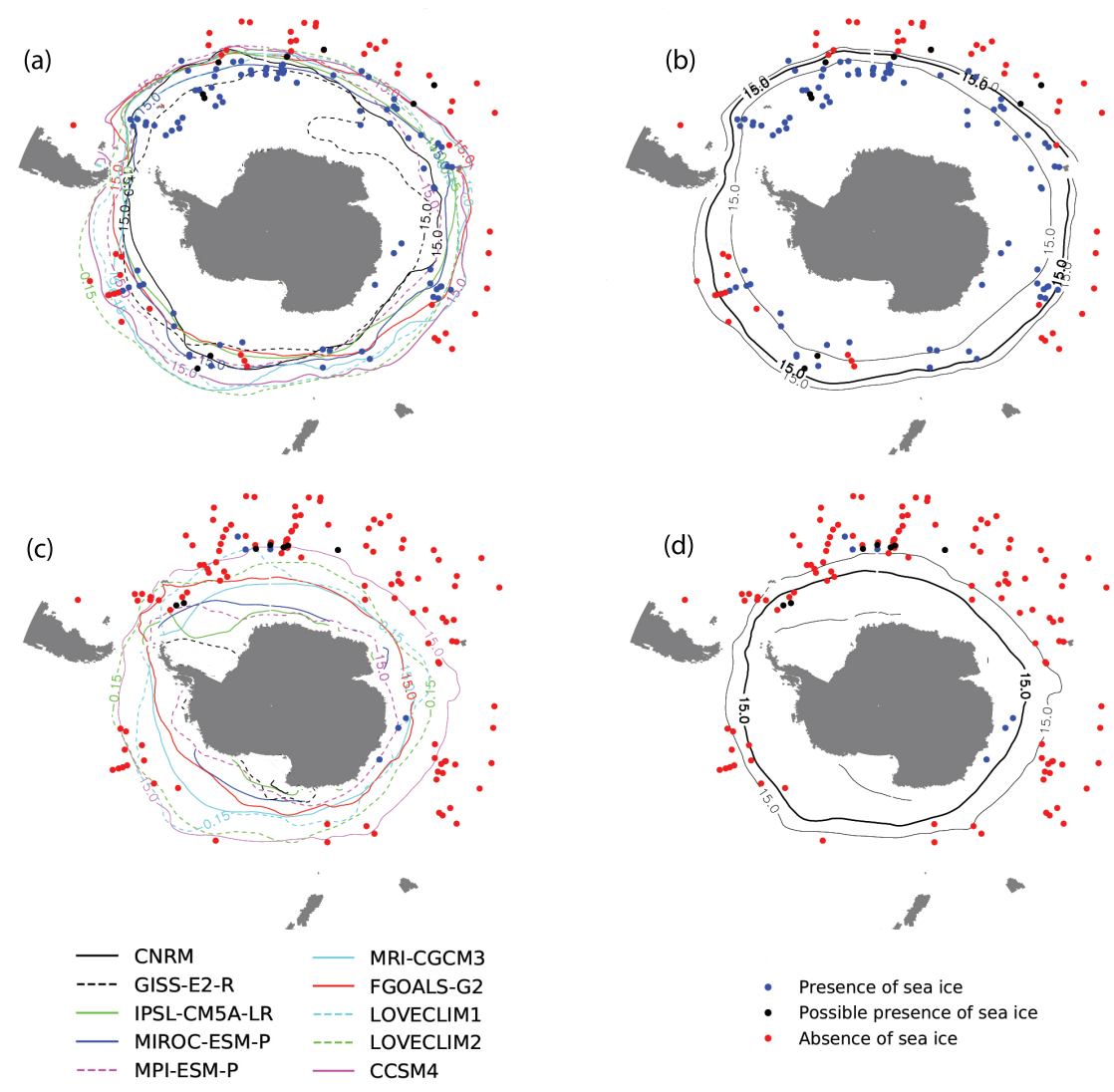

Figure 1. PMIP3 and LOVECLIM austral winter (a,b), and austral summer (c,d) simulated sea ice concentration at $15 \%$. All 10 models are shown in the left panels (a,c) and the multi model mean \pm one standard deviation is shown in the right panels (b,d). Blue, black, and red filled points represent the sediment core proxy data used for the study. 
https://doi.org/10.5194/cp-2020-155

Preprint. Discussion started: 22 December 2020

(c) Author(s) 2020. CC BY 4.0 License.
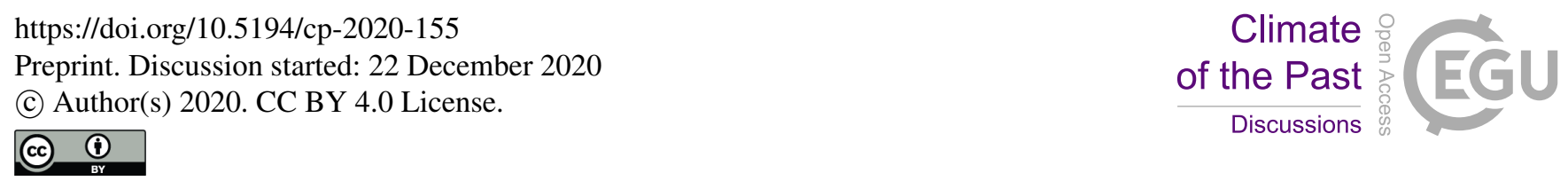

During austral winter, the simulated multi-model mean sea-ice edge lies at $\sim 51.5^{\circ} \mathrm{S}$ with one standard deviation equating to $1.5^{\circ}$ north and $4^{\circ}$ south of the multi-model mean (Figure $1 \mathrm{~b}$ ). The standard deviation is not symmetric because it is calculated based on the zonally averaged sea-ice concentration at $15 \%$, which varies with latitude. Outside of the zonally averaged mean, large regional differences are found. In the GISS-E2-R simulation (dashed black-Figure 1a), very little sea ice is simulated in the Indian Ocean sector $\left(15^{\circ} \mathrm{E}\right.$ to $\left.75^{\circ} \mathrm{E}\right)$. The standard deviation south of the multi-model mean also increases to $7^{\circ}$ in the Pacific sector $\left(175^{\circ} \mathrm{E}\right.$ to $\left.140^{\circ} \mathrm{W}\right)$ of the Southern Ocean. This increase in standard deviation south of the multi-model mean is in part due to GISS-E2-R (dashed black-Figure 1a), which simulates a sea-ice edge at $57^{\circ} \mathrm{S}$ within the Indian sector. On the other hand, the simulated sea-ice edge for all 10 models is located further poleward on the western edge of the Pacific, with the multi-model mean sea-ice edge located at $56^{\circ} \mathrm{S}$ and the standard deviation decreasing to $1^{\circ}$ south of the mean in that region.

In comparison to the proxy data, the austral winter multi-model mean simulates $87 \%$ of the sediment core locations correctly. Seven of the ten models show greater than $79 \%$ model-data agreement, five of which equal or exceed $80 \%$. At $87 \%$, FGOALSG2 (red) simulates the highest agreement among individual models and therefore fits the reconstructed sea-ice extent during austral winter best (Table 3).

All of the models, except GISS-E2-R (dashed black), fall within $\pm 2^{\circ}$ of the multi model mean winter sea-ice edge at $51.5^{\circ}$ S. LOVECLIM1 (dashed cyan) and LOVECLIM2 (dashed green) display a mean simulated winter sea-ice edge closest to the multi-model mean at $52^{\circ}$ and $51^{\circ} \mathrm{S}$, respectively (Figure 1a and Table 3).

A much larger spread between models is obtained during austral summer (Figures 1c, 1d) with a multi-model sea-ice edge at $60.5^{\circ} \mathrm{S}$ and one standard deviation of $3^{\circ}$ north and $10^{\circ}$ south of the mean. Similar to the austral winter distribution, the largest sea-ice cover is simulated by CCSM4 (pink) with a sea-ice edge at $\sim 55.5^{\circ} \mathrm{S}$. Three models (CNRM - black, GISS-E2-R dashed black, IPSL-CM5A-LR - green) only simulate sea ice around the Ross and Weddell Seas and are otherwise ice-free. CNRM (black) simulates the least amount of sea ice at or above $15 \%$ concentration with sea ice only simulated in a small region of the Ross Sea (Figure 1c). LOVECLIM1 simulates a sea-ice edge at $59.5^{\circ} \mathrm{S}$, in closest agreement with the multi-model mean.

For austral summer, only six core locations out of 132 display a relative abundance of $F$. obliquecostata greater than 3\% (Figure 1c,d; blue filled circles), indicating the presence of summer sea ice (SSI). Relative abundances of F. obliquecostata are between $2 \%$ and $3 \%$ in seven additional cores from the Atlantic sector of the Southern Ocean (Figure 1c,d; black filled circles), suggesting the possible presence of summer sea ice. The remaining 119 core locations have a relative abundance of $F$. obliquecostata $<2 \%$ (including 64 cores with $0 \%$ ), indicating ice-free conditions. Of the six locations indicating the presence of sea ice (blue filled circles), three cores are located in the Indian sector at $\sim 63^{\circ} \mathrm{S}$ south of the multi-model mean, whereas the other three are in the Atlantic sector at $\sim 53^{\circ} \mathrm{S}$ north of the multi-model mean and the +1 standard deviation (Figure 1d). Five of the seven locations showing the possible presence of SSI (black filled circles) are also located north of the multi-model mean and the northward standard deviation (Figure 1d). We note that the eight locations from the Atlantic sector representing a presence or possible presence of sea ice are bordered by cores suggesting ice-free conditions, possibly indicating a sea-ice tongue protruding from the Weddell Sea. $91 \%$ of the 119 locations representing ice-free conditions fall north of the multimodel mean, leading us to suggest that the multi-model mean at $60.5^{\circ} \mathrm{S}$ is an upper estimate of the plausible LGM austral summer sea-ice extent. Equatorward of the multi-model mean, CCSM4 (pink) simulates sea ice in locations where the proxy 
records suggest ice-free conditions in all sectors of the Southern Ocean, thus most likely over-estimating austral summer seaice cover. Furthermore, LOVECLIM2 (dashed green), and LOVECLIM1 (dashed cyan) might overestimate the sea-ice cover in the Pacific and Atlantic sectors of the Southern Ocean, while FGOALS-G2 (red) simulates sea ice north of the Weddell Sea where three proxy locations suggest ice-free conditions.

In the next section, we focus our analysis on austral summer sea-ice extent, evaluating differences between the models and the potential reasons for the observed inter-model spread. We focus our analysis on the thermodynamic and dynamic controls on sea-ice extent, as ocean temperatures exert a significant control on sea-ice formation and melt, and wind-stress affects sea-ice transport.

\subsection{Thermodynamic control on summer sea-ice extent}

It is expected that there should be a robust relationship between sea-ice cover and SST in the Southern Ocean. We thus first look at the relationship between zonally averaged austral summer SSTs in the Southern Ocean and sea-ice edge and extent (Figure 2a,b).

For seven out of ten simulations, the zonally averaged summer SST between $50^{\circ} \mathrm{S}$ and $75^{\circ} \mathrm{S}$ are between $1.5^{\circ}$ and $3^{\circ} \mathrm{C}$. By comparison, the mean summer SST estimate from proxy records present in the compilation and falling within this latitudinal band is $1.52{ }^{\circ} \mathrm{C} \pm 0.67{ }^{\circ} \mathrm{C}$. Two models averages are significantly warmer (GISS $=3.71{ }^{\circ} \mathrm{C}$ and $\mathrm{CNRM}=5.58{ }^{\circ} \mathrm{C}$ ), and one is significantly colder $\left(\mathrm{CCSM} 4=-0.52{ }^{\circ} \mathrm{C}\right)$. The lower the mean SST, the larger the sea-ice extent with a quasi linear relationship between the two, particularly if excluding the three outliers. Using a linear fit line, and taking into account all the simulations, the summer sea-ice edge and extent are correlated with SST calculated by $\mathrm{R}^{2}$ values of 0.81 and 0.82 , respectively (Figure 2a, b).

All of the models simulate a mean sea-ice edge near the $0{ }^{\circ} \mathrm{C}$ isoline, apart from GISS-E2-R (and CNRM, which simulates a sea-ice edge at the Antarctic coast, Figure 2c). Equatorward of the sea-ice edge, all models display a significant SST increase with decreasing latitudes. Summer SSTs as estimated from proxy records are shown as grey circles (Figure 2c). They suggest a mean SST of $1.41^{\circ} \mathrm{C}$ south of $52^{\circ} \mathrm{S}$, and northward of which they increase significantly with decreasing latitudes. The SST latitudinal variations in the models and proxies display significant differences, with some models being consistently warmer than the proxies (CNRM, GISS-E2-R), whereas others with a significant summer sea-ice cover underestimate the proxy-based SSTs south of $60^{\circ} \mathrm{S}$ (e.g. CCSM4, LOVECLIM, FGOALS-G2).

Both CNRM and GISS-E2-R seem to consistently over-estimate austral summer SSTs (Fig. 2c). CNRM simulates a mean SST of $5.6^{\circ} \mathrm{C}$ south of $50^{\circ} \mathrm{S}$, which explains the minimal amount of sea ice simulated (Fig. 2a, black filled triangle). GISS-E2$\mathrm{R}$ has the second lowest sea-ice extent and simulates a mean SST of $3.7^{\circ} \mathrm{C}$ south of $50^{\circ} \mathrm{S}$ (black filled circle). As highlighted in the methods, the sea-ice edge is not an all-encompassing metric for sea-ice cover due to our definition. For GISS-E2-R, the sea-ice edge of $65.5^{\circ} \mathrm{S}$ is calculated only using the Ross Sea, due to the lack of simulated sea ice around the rest of Antarctica in austral summer (Table 3). 

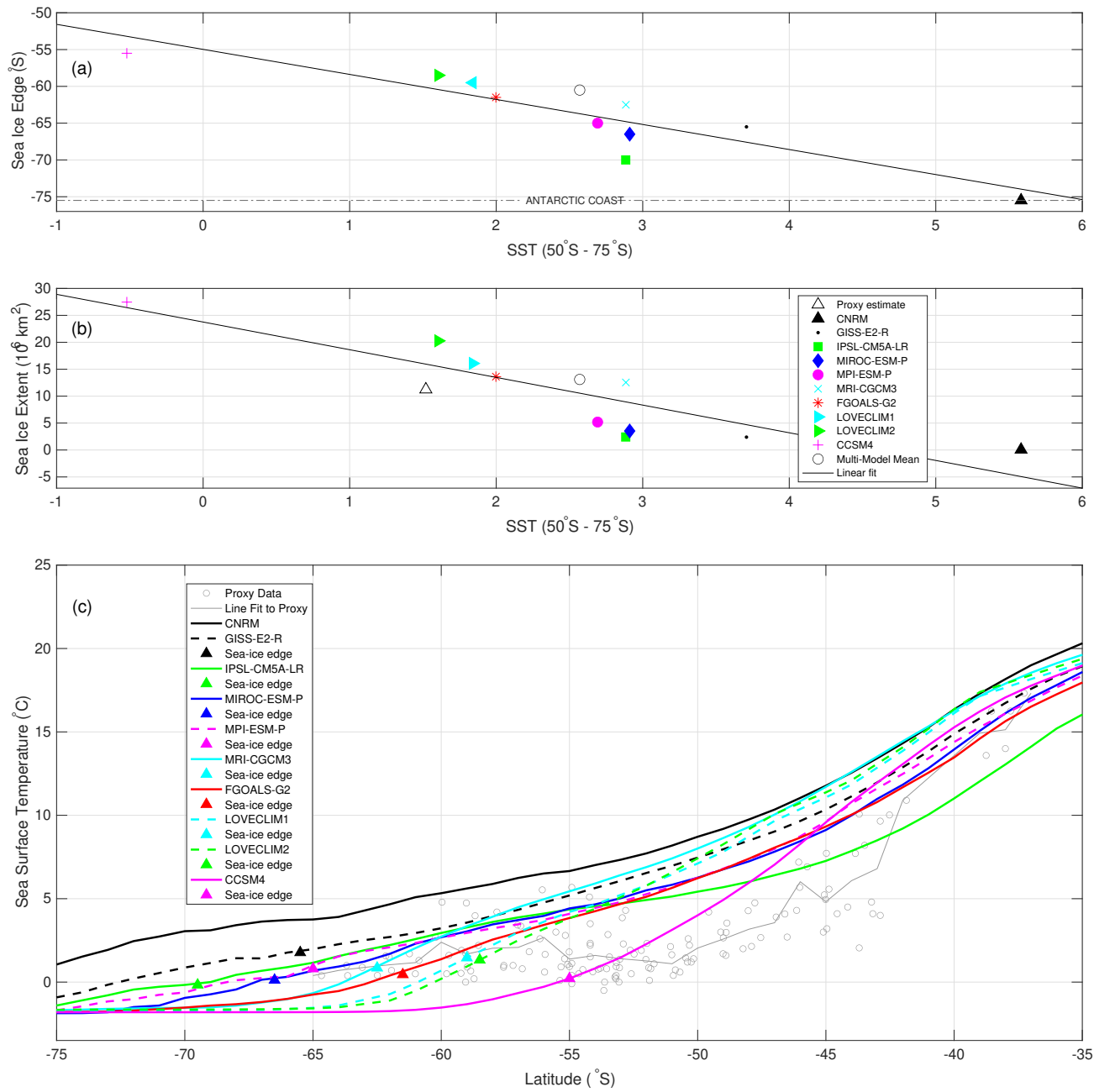

Figure 2. Austral summer sea ice and SST. a) Sea-ice edge vs. SST $\left(50^{\circ}-75^{\circ} \mathrm{S}\right)$ b) Sea-ice extent vs. SST $\left(50^{\circ}-75^{\circ} \mathrm{S}\right)$. Proxy summer sea-ice extent was estimated using available austral summer sea ice and SST reconstructions. c) Zonally averaged SST values from $35^{\circ}-75^{\circ} \mathrm{S}$. Filled triangles represent sea-ice edge for each model. Grey circles represent sediment core proxy data with a grey line fit for the data points. 
https://doi.org/10.5194/cp-2020-155

Preprint. Discussion started: 22 December 2020

(c) Author(s) 2020. CC BY 4.0 License.

(c) (i)

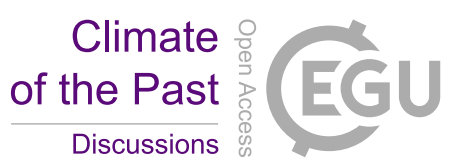

Table 3. Simulated sea ice characteristics, summer sea surface temperatures and meridional transports ordered based on total sea-ice extent (lowest to highest). Model data agreement is calculated as a percent of the correctly simulated sediment cores (presence of sea ice or ice-free conditions). Statistics on summer sea ice agreement have to be interpreted with caution as only 6 out of 133 cores suggest sea-ice cover. This implies that models with no simulated austral summer sea ice might have very good agreement with proxy data but could still significantly under-estimate the sea-ice cover. The austral summer Southern Ocean SST is latitudinally averaged over $75^{\circ} \mathrm{S}$ to $50^{\circ} \mathrm{S}$. The austral summer sea-ice edge is taken at the mean 15\% concentration. Calculated root-mean-squared error (RMSE) values use the summer SSTs from proxy data in comparison to the modeled summer SST output. Simulated austral summer zonally averaged meridional advective volume transport is calculated over $75^{\circ} \mathrm{S}$ to $50^{\circ} \mathrm{S}$ for the first $100 \mathrm{~m}$ depth for each model. Positive numbers represent equatorward transport and negative numbers represent poleward transport. LOVECLIM results are calculated from annual mean data.

\begin{tabular}{|c|c|c|c|c|c|c|c|c|}
\hline $\begin{array}{l}\text { Model } \\
\text { name }\end{array}$ & $\begin{array}{l}\text { Austral } \\
\text { winter } \\
\text { sea-ice } \\
\text { agreement } \\
(\%)\end{array}$ & $\begin{array}{l}\text { Austral } \\
\text { summer } \\
\text { sea-ice } \\
\text { agreement } \\
(\%)\end{array}$ & $\begin{array}{l}\text { Austral } \\
\text { summer } \\
\text { average } \\
\text { southern } \\
\text { ocean SST } \\
\left({ }^{\circ} \mathrm{C}\right)\end{array}$ & $\begin{array}{l}\text { Root mean } \\
\text { square } \\
\text { value } \\
\text { (RMSE) }\end{array}$ & $\begin{array}{l}\text { Summer } \\
\text { average } \\
\text { meridional } \\
\text { advective } \\
\text { volume } \\
\text { transport } \\
(\mathrm{Sv})\end{array}$ & $\begin{array}{l}\text { Austral } \\
\text { winter } \\
\text { sea-ice } \\
\text { edge }\left({ }^{\circ} \mathrm{S}\right)\end{array}$ & $\begin{array}{l}\text { Austral } \\
\text { summer } \\
\text { sea-ice } \\
\text { edge }\left({ }^{\circ} \mathrm{S}\right)\end{array}$ & $\begin{array}{l}\text { Austral } \\
\text { summer } \\
\text { sea-ice } \\
\text { extent } \\
\left(10^{6} \mathrm{~km}^{2}\right)\end{array}$ \\
\hline CNRM & 67.79 & 95.45 & 5.58 & 3.47 & 0.5209 & $53.5^{\circ} \mathrm{S}$ & $75.5^{\circ} \mathrm{S}$ & .06047 \\
\hline $\begin{array}{l}\text { GISS-E2- } \\
\text { R }\end{array}$ & 61.74 & 95.45 & 3.71 & 1.95 & 0.7307 & $58^{\circ} \mathrm{S}$ & $65.5^{\circ} \mathrm{S}^{*}$ & 2.391 \\
\hline $\begin{array}{l}\text { IPSL- } \\
\text { CM5A-LR }\end{array}$ & 79.87 & 95.45 & 2.88 & 0.83 & -0.2546 & $52.5^{\circ} \mathrm{S}$ & $70^{\circ} \mathrm{S} * *$ & 2.414 \\
\hline $\begin{array}{l}\text { MIROC- } \\
\text { ESM-P }\end{array}$ & 75.17 & 95.45 & 2.99 & 1.37 & 0.6317 & $53.5^{\circ} \mathrm{S}$ & $66.5^{\circ} \mathrm{S}^{* *}$ & 3.530 \\
\hline $\begin{array}{l}\text { MPI- } \\
\text { ESM-P }\end{array}$ & 79.19 & 93.18 & 2.69 & 1.37 & 1.491 & $52.5^{\circ} \mathrm{S}$ & $65^{\circ} \mathrm{S}$ & 5.187 \\
\hline $\begin{array}{l}\text { MRI- } \\
\text { CGCM3 }\end{array}$ & 84.56 & 97.73 & 2.89 & 3.65 & 1.167 & $50^{\circ} \mathrm{S}$ & $62.5^{\circ} \mathrm{S}$ & 12.54 \\
\hline $\begin{array}{l}\text { FGOALS- } \\
\text { G2 }\end{array}$ & 87.25 & 93.18 & 2.00 & 0.65 & 0.5172 & $50.5^{\circ} \mathrm{S}$ & $61.5^{\circ} \mathrm{S}$ & 13.62 \\
\hline LOVECLIM1 & 179.19 & 86.36 & 1.84 & 1.60 & 2.303 & $52^{\circ} \mathrm{S}$ & $59.5^{\circ} \mathrm{S}$ & 16.08 \\
\hline LOVECLIM2 & 286.58 & 85.61 & 1.61 & 1.61 & 1.771 & $51^{\circ} \mathrm{S}$ & $58.5^{\circ} \mathrm{S}$ & 20.27 \\
\hline CCSM4 & 79.87 & 75.76 & -0.52 & 1.28 & 1.714 & $49.5^{\circ} \mathrm{S}$ & $55.5^{\circ} \mathrm{S}$ & 27.46 \\
\hline $\begin{array}{l}\text { Proxy esti- } \\
\text { mate }\end{array}$ & - & - & 1.52 & - & - & - & - & 11.24 \\
\hline $\begin{array}{l}\text { Multi- } \\
\text { Model }\end{array}$ & 86.58 & 92.42 & 2.57 & 1.77 & 0.58 & $51.5^{\circ} \mathrm{S}$ & $60.5^{\circ} \mathrm{S}$ & 13.10 \\
\hline Mean & & & & & & & & \\
\hline
\end{tabular}


https://doi.org/10.5194/cp-2020-155

Preprint. Discussion started: 22 December 2020

(c) Author(s) 2020. CC BY 4.0 License.

\section{(c) $\underset{\mathrm{BY}}{\mathrm{BV}}$}

Conversely, CCSM4 simulates the largest sea-ice cover, reaching $55.5^{\circ} \mathrm{S}$, and is the only model displaying a mean SST south of $50^{\circ} \mathrm{S}$ that is negative (Fig. 2a and 2b, Table 3). The CCSM4 simulated Southern Ocean summer SSTs are significantly lower than the other models south of $48^{\circ} \mathrm{S}$ and lower than all of the proxy estimates south of $55^{\circ} \mathrm{S}$ (Figure 2, pink line).

The IPSL-CM5A-LR model (Figure 2c, green line) simulates a higher zonally averaged SST between the Antarctic coast and $60^{\circ} \mathrm{S}$ than all of the models, outside of the two warm outliers (CNRM-black and GISS-E2-R-dashed black). These high simulated SST values could potentially explain the low sea-ice cover in the IPSL-CM5A-LR simulation. However, it is interesting to note that IPSL-CM5A-LR displays the lowest SST meridional temperature gradient south of $40^{\circ} \mathrm{S}$, thus simulating relatively low SSTs north of $55^{\circ} \mathrm{S}$.

The remaining models (FGOALS-G2-red, MIROC-ESM-P-blue, MRI-CGCM3-cyan, MPI-ESM-P-dashed pink, and the two LOVECLIM simulations: LOVECLIM1, dashed cyan, and LOVECLIM2, dashed green) display a mean SST of $1.5^{\circ}$ to $3^{\circ} \mathrm{C}$ south of $50^{\circ} \mathrm{S}$, and a mean austral summer sea-ice edge between $58.5^{\circ}$ and $66.5^{\circ} \mathrm{S}$.

Only 6 out of the 149 LGM samples contained in the compilation show the common presence of SSI (Figure 1c-d, blue filled circles) while 7 samples suggest the episodic presence of SSI (Figure 1c-d, black filled circles). Obviously, it is impossible to infer the Antarctic-wide SSI extent based on such a restricted number of control points. However, very low SSTs $\left(\sim 0-0.5^{\circ} \mathrm{C}\right)$ were concomitantly reconstructed in the 6 samples showing SSI presence (Gersonde et al., 2005) in agreement with modern environments whereby SSI (Schweitzer, 1995) generally lies south of the $0{ }^{\circ} \mathrm{C}$ summer surface isotherm (Locarnini et al., 2010). We therefore made use of this relation and of summer SST reconstructions (e.g., Benz et al., 2016; Gersonde et al., 2005) to complement the SSI estimates and infer the most probable SSI extent at the LGM. After subtracting the LGM surface of Antarctica (17.10x $10^{6} \mathrm{~km}^{2}$; (Bentley et al., 2014)) from the estimated SSI total extent, we arrive at an estimate of the net SSI extent of $11.24 \times 10^{6} \mathrm{~km}^{2}$. This proxy-based net SSI extent is closest to the $12.54 \times 10^{6} \mathrm{~km}^{2}$ extent simulated by MRI-CGCM3. However, the simulated SST $\left(50^{\circ}-75^{\circ} \mathrm{S}\right)$ by MRI-CGCM3 is $1.37^{\circ} \mathrm{C}$ warmer than the proxy SST reconstruction (Figure 2b, Table 3).

Figure 3 shows each model's simulated SST compared to the available SST proxy data. The proxy data is regionally variable, with lower temperatures (darker blue points) in the Atlantic and Pacific sectors and higher temperatures (lighter blue points) in the Indian sector. There are more records at lower latitudes in the Atlantic and Indian sectors, which can be seen plotted in Figure S2. Consistent with the previous analysis, CNRM and GISS-E2-R simulate higher SSTs than inferred from proxies, while CCSM4 simulates lower temperatures than inferred from proxies.

Using the proxy data as observations, we calculate the root-mean-squared error (RMSE) between simulated SSTs and observations for each model (Table 3). The model with the lowest RMSE value (0.65), representing the model for which simulated SSTs fit the reconstructions best, is the FGOALS-G2 model. IPSL-CM5A-LR has the second lowest RMSE value (0.83), potentially due to the extremely cold SSTs north of $52^{\circ} \mathrm{S}$. The models with the highest RMSE values are MRI-ESM-P (2.89) and CNRM (3.47).

We further explore the vertical thermal structure of the models (Figure 4). The CNRM experiment stands out as simulating significantly warmer conditions everywhere in the ocean compared to any other model, with potential temperatures below $0^{\circ} \mathrm{C}$ only deeper than 1000m depth. The GISS-E2-R and ISPL-CM5A-LR experiments, which both simulate low austral summer 

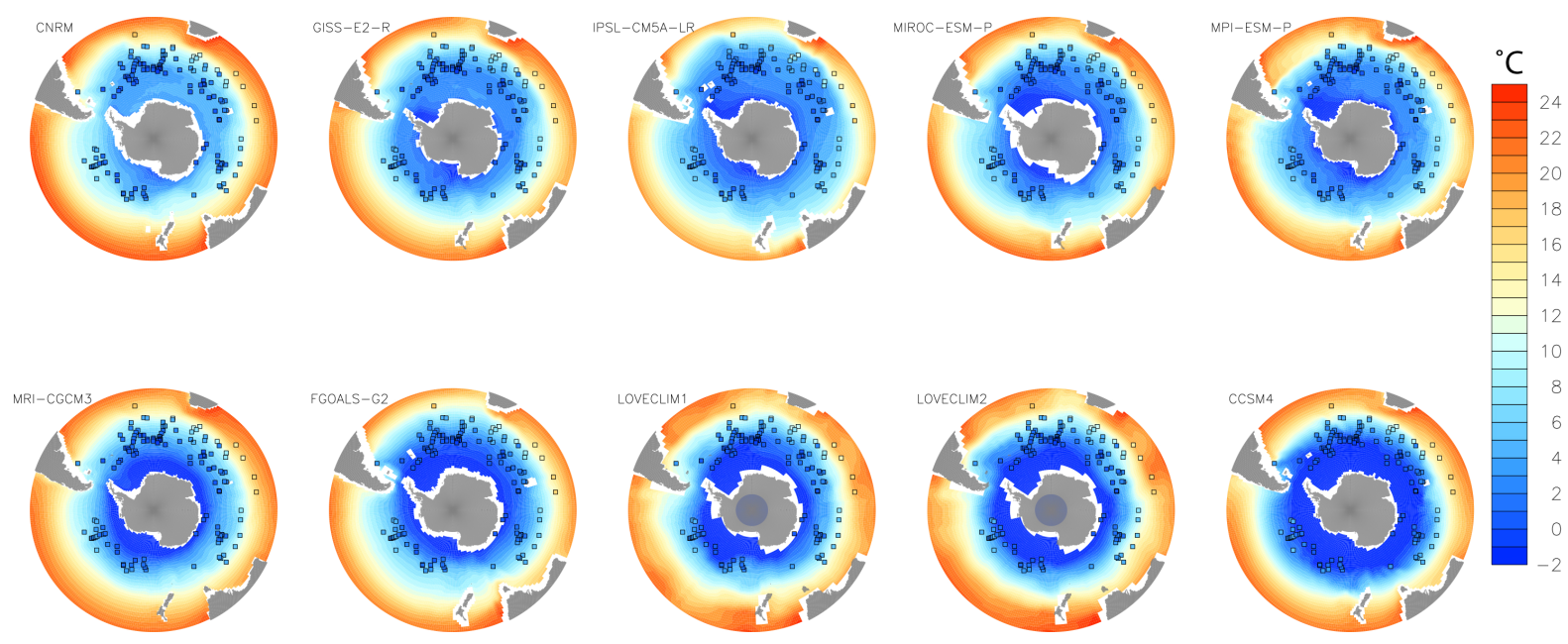

Figure 3. PMIP3 and LOVECLIM austral summer simulated SSTs with SST reconstruction data overlain. Fill color inside each SST reconstruction data point represents paleo SSTs at each location.

sea-ice cover and similar Atlantic Meridional Overturning Circulations (AMOC) (Muglia and Schmittner, 2015), display very different temperature structures. This is most likely because NADW, which is brought up in southern high-latitude upper waters via Southern Ocean upwelling, is relatively warm in GISS-E2-R and conversely relatively cold in IPSL-CM5A-LR. This difference in northern end member water masses could explain the relatively weak latitudinal potential temperature gradient in the Southern Ocean in IPSL-CM5A-LR, and the relatively warm conditions in GISS-E2-R. The MIROC-ESM-P and MPIESM-P experiments also simulate relatively warm NADW, which could contribute to the relatively low austral summer sea-ice cover.

Although these different thermal characteristics impact model sea-ice cover, apparent variability between models demonstrates that factors outside of SST and potential temperature also determine the different sea-ice distribution in these models.

\subsection{Dynamic control on summer sea-ice extent}

Due to its impact on Southern Ocean circulation and sea-ice transport, the strength and location of the southern hemispheric westerly and polar easterly winds also impact sea-ice distribution (Purich et al., 2016; Holland and Kwok, 2012). Figure 5 a shows the zonally averaged wind stress curl south of $30^{\circ} \mathrm{S}$ of 6 simulations that display similar mean Southern Ocean SSTs (FGOALS-G2-red, MIROC-ESM-P-blue, MRI-CGCM3-cyan, MPI-ESM-P-dashed pink, LOVECLIM1-dashed cyan, LOVECLIM2-dashed green), with their mean latitude of sea-ice edge overlaid. For each of these models, the sea-ice edge falls within 2-3 degrees of their zonal mean wind stress curl peak (Figure 5a). The wind stress curl maximum represents divergence of the Ekman transport, indicating the maximum upwelling area. The close link between maximum wind stress curl and summer sea-ice edge in the FGOALS-G2, MIROC-ESM-P, MRI-CGCM3, MPI-ESM-P and the two LOVECLIM simulations suggests that Southern Ocean dynamics significantly impact the summer sea-ice edge for these models. 


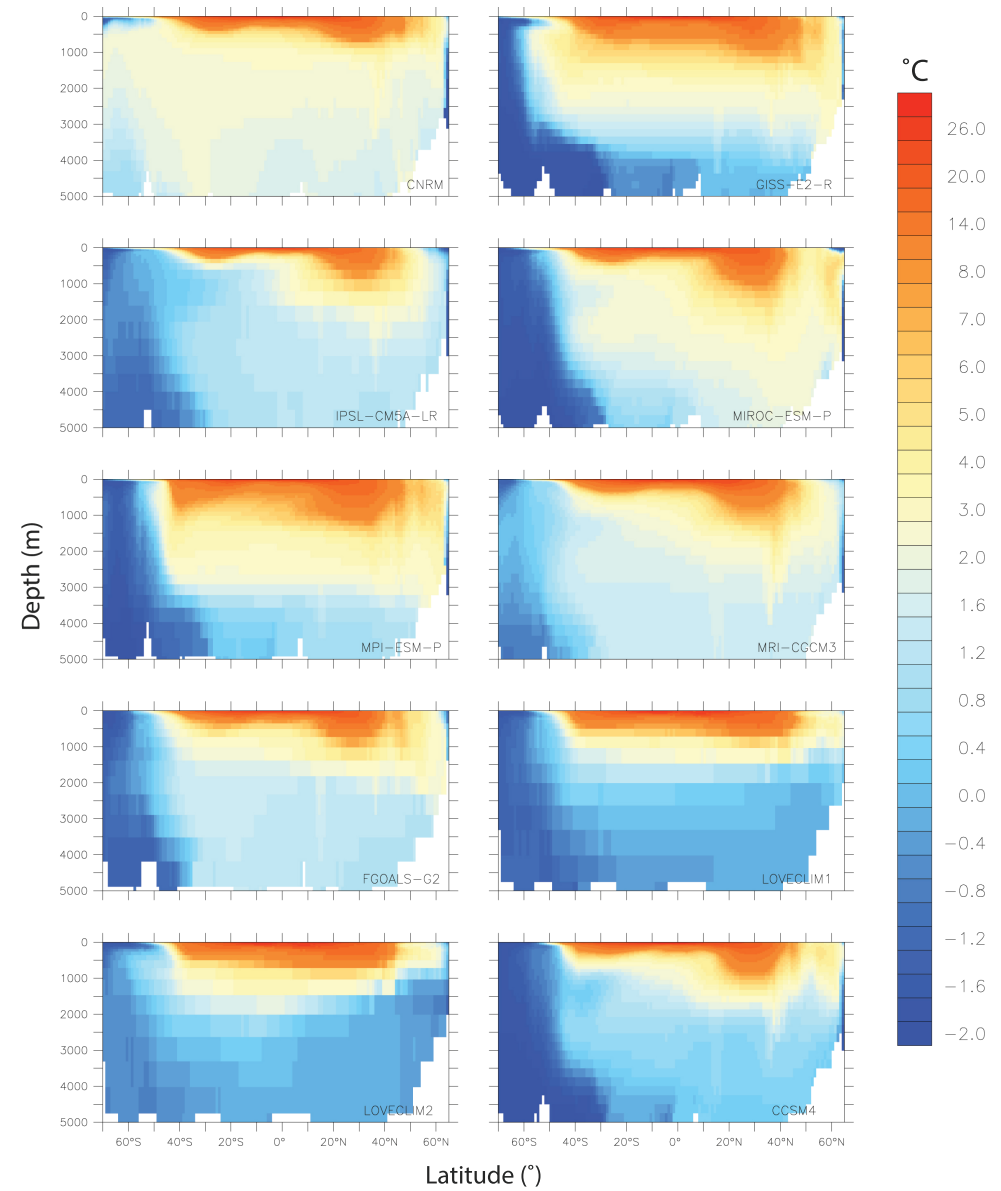

Figure 4. Zonally averaged austral summer potential temperature profile for PMIP3 and LOVECLIM models in the Atlantic.

In contrast, Figure $5 \mathrm{~b}$ shows the models we designate as outliers as they are either significantly warmer (CNRM, GISS-E2$\mathrm{R}$ ) or colder (CCSM4) than other models and paleo-proxy estimates. IPSL-CM5A-LR is also included here as its sea-ice edge is more than $2^{\circ}$ outside of its wind stress curl peak, similar to CNRM and CCSM4 (Figure 5b). GISS-E2-R falls closest to its peak, but with its sea-ice edge calculated only from the Ross Sea, we believe the dynamic effects of the wind stress curl would not have caused the absence of simulated sea ice in the other regions of the Antarctic coast. Apart from the 'pseudo' sea-ice edge from GISS-E2-R, this figure shows that the divergence due to the wind stress curl does not have a large impact on summer sea ice in these models as CNRM and GISS-E2-R are likely too warm and CCSM4 is too cold. The drivers of sea ice for IPSL-CM5A-LR seem a bit more complex. While IPSL-CM5A-LR simulates the same mean SST south of 50 $\mathrm{S}$ as MIROC-ESM-P $\left(2.9^{\circ} \mathrm{C}\right.$, Table 3$)$, IPSL-CM5A-LR sea-ice extent is significantly lower with its edge situated closer to the Antarctic coast compared to MIROC-ESM-P. To understand why these two models simulate different sea-ice dynamics, we calculate the mean meridional advective transport within the upper $100 \mathrm{~m}$ in the Southern Ocean $\left(50^{\circ} \mathrm{S}\right.$ to $\left.75^{\circ} \mathrm{S}\right)$ for each 

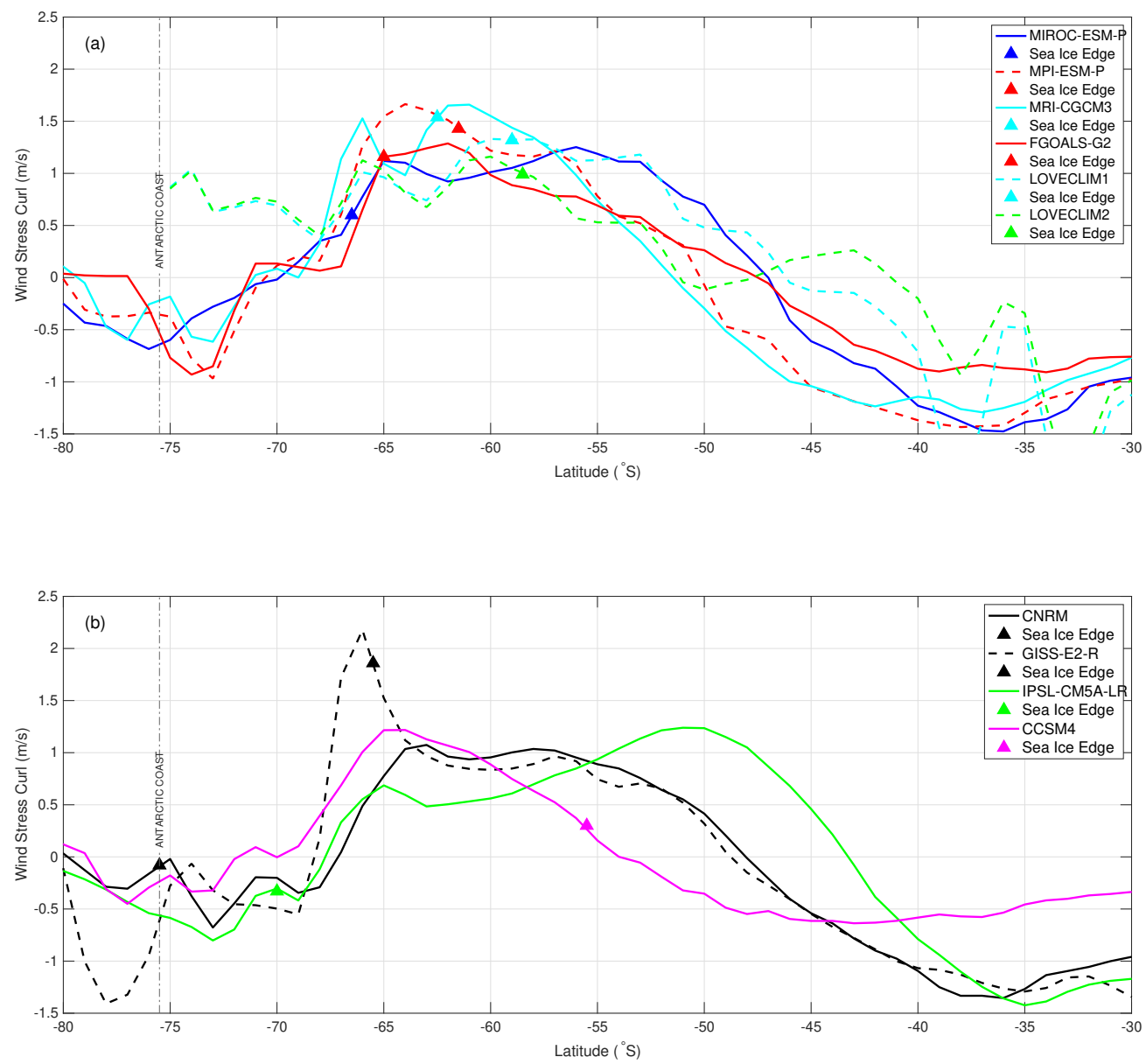

Figure 5. Zonally averaged austral summer wind stress curl vs. latitude. a) shows the models we expect Southern Ocean dynamics to significantly impact summer sea-ice edge b) shows the models we expect ocean temperatures to play a larger role impacting summer sea-ice edge. Each model's ice edge is represented with a filled triangle.

PMIP3 model. We find that all models simulate an equatorward surface transport, apart from IPSL-CM5A-LR, which displays a poleward zonal mean surface transport (Table 3). IPSL-CM5A-LR also displays the most equatorward windstress curl peak, thus potentially explaining the lower than average SSTs north of the windstress curl peak, and higher than average SSTs south of the peak, with advection of lower latitude waters towards the Antarctic coast. 
https://doi.org/10.5194/cp-2020-155

Preprint. Discussion started: 22 December 2020

(c) Author(s) 2020. CC BY 4.0 License.

\section{(c) (i)}

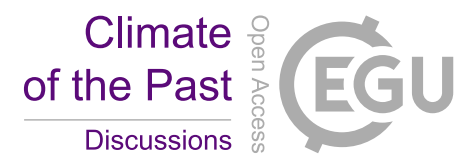

\section{Discussion and conclusions}

We have evaluated the Antarctic seasonal sea-ice distributions for eight PMIP3 LGM simulations and two LOVECLIM LGM simulations and compared them with available paleo-proxy records. Apart from one model (GISS-E2-R), which displays little sea ice in the Indian Ocean sector of the Southern Ocean, austral winter simulations are in global agreement with the existing proxy data, with a sea-ice edge at $\sim 51.5^{\circ} \mathrm{S}\left(1\right.$ sigma range: $\left.50^{\circ}-55.5^{\circ} \mathrm{S}\right)$. FGOALS-G2 (red) best fits the distribution shape of the proxy data across the three regions and is in agreement with $87 \%$ of the proxy data points. MRI-CGCM3 (cyan), LOVECLIM2 (dashed cyan), CCSM4 (pink), and IPSL (green) austral winter sea-ice cover also all closely resemble the data distribution and are in agreement with at least $80 \%$ of the proxy data points. A previous study found similar results, identifying CCSM4 and MRI-CGCM3 LGM maximum and minimum Southern Hemisphere sea-ice area in closest agreement to the paleoreconstructions (Marzocchi and Jansen, 2017).

However, the models exhibit large differences in austral summer sea-ice coverage with one model simulating a sea-ice edge at $55^{\circ} \mathrm{S}$ (CCSM4), while two others (GISS-E2-R and CNRM) simulate an almost ice-free Southern Ocean. Our comparison with available summer sea-ice records is limited as there are only six sediment core locations that reflect the presence of summer sea ice (Allen et al., 2011; Benz et al., 2016; Ferry et al., 2015; Gersonde et al., 2005; Ghadi et al., 2020; Nair et al., 2019; Xiao et al., 2016). Additionally, these six locations are grouped within two small regions. Three of the cores are located in the Indian sector at $\sim 63^{\circ} \mathrm{S}$, along the Antarctic coastal shelf. The other three are located in the Atlantic sector at $\sim 53^{\circ} \mathrm{S}$ and are bordered by other records suggesting ice-free conditions immediately northward, thus potentially suggesting sporadic sea-ice advance to that latitude. In the same way, cores from the Indian and Pacific sectors in which F. obliquecostata counts were published suggest ice-free conditions at $60-63^{\circ} \mathrm{S}$ (Figure 1c,d). Nevertheless, the multi-model mean simulates a summer sea-ice edge at $60.5^{\circ} \mathrm{S}$, which agrees with $92 \%$ of the proxy data though it may appear too expanded in the Indian and Pacific sectors while not expanded enough in the Atlantic sector of the Southern Ocean.

To try to better constrain the austral summer Southern Ocean conditions, we compare the simulations with available summer SST reconstructions. This model-data comparison in Figure 2 shows that the simulated SST decreases more gradually with latitude than in the proxy reconstructions. However, this figure uses only zonally averaged SSTs. When viewing all of the ocean basins, Figure 3 shows that colder models (LOVECLIM 1 and 2, CCSM4) display a larger simulated SST gradient. As prior research has shown that CMIP5 models display a warm bias over the Southern Ocean (Meijers, 2014), there is potential for this SST gradient discrepancy to diminish as models improve. Our analysis suggests that the models simulating little to no summer sea ice are likely too warm, and thus under-estimate the summer sea-ice edge. The simulated NADW in these models is also quite warm, thus likely leading to a warm bias in the Southern Ocean.

The models also display a relatively large range $\left(\sim-2^{\circ}\right.$ to $\left.4^{\circ} \mathrm{C}\right)$ of temperatures in the deep Atlantic Ocean (Figure 4). Only a few paleo-records of deep ocean temperature are available for the LGM, but they suggest ocean temperatures below $0^{\circ} \mathrm{C}$ throughout the deep Atlantic (Adkins et al., 2002). In the Southwest Pacific at ODP Site 1123, Mg/Ca records find deep ocean temperatures of $-1.1 \pm 0.3{ }^{\circ} \mathrm{C}$ at the LGM (Elderfield et al., 2010). Additional data would help constrain deep ocean temperature and water masses distribution, and thus total ocean heat and carbon content. 
https://doi.org/10.5194/cp-2020-155

Preprint. Discussion started: 22 December 2020

(c) Author(s) 2020. CC BY 4.0 License.

\section{(c) $\underset{\mathrm{BY}}{\mathrm{BV}}$}

Climate

of the Past

Discussions

Our analysis also included two LGM experiments performed with LOVECLIM, in which the oceanic circulation was varied by addition of meltwater and changes in southern hemispheric westerly windstress (Menviel et al., 2017). Despite significant differences in oceanic circulation in these two simulations, with weaker NADW and AABW in LOVECLIM2 compared to LOVECLIM1, the sea-ice cover differences between these two runs are much smaller than compared to other models. Apart from FGOALS-G2, which simulate a very strong LGM AMOC, the LGM AMOC strengths in the other PMIP3 models are similar at 21-23 Sv (Muglia and Schmittner, 2015). This indicates that the primary control on LGM austral summer sea-ice cover is not linked to the strength of the AMOC. There is also no link between the equilibrium climate sensitivity (ECS) of these models and their austral summer sea-ice cover, with the three models displaying the least amount of sea-ice exhibiting ECS of $3.3^{\circ} \mathrm{C}$ for CNRM, $2.1^{\circ} \mathrm{C}$ for GISS-E2-R and $4.2^{\circ} \mathrm{C}$ for IPSL-CM5A-LR, while the two models with the most sea-ice have an ECS of $2.8^{\circ} \mathrm{C}$ (CCSM4 and LOVECLIM).

For the models simulating relatively similar austral summer SST values (FGOALS-G2-red, MIROC-ESM-P-blue, MRICGCM3-cyan, MPI-ESM-P-cyan, LOVECLIM1-dashed cyan, LOVECLIM2-dashed green), our analysis suggests the location of their respective sea-ice edge is linked to the position of the maximum windstress curl. The maximum wind stress curl corresponds to a maximum Ekman transport divergence, creating maximum upwelling strength in that region. This can impact sea ice both thermodynamically and dynamically, as upwelling is often linked with ocean heat release while the Ekman transport divergence can lead to strong equatorward transport of sea ice into warmer SSTs. Given the uncertainties that surround the magnitude and the position of the Southern Hemisphere westerlies at the LGM (e.g., Kohfeld et al., 2013; Sime et al., 2016), this casts additional uncertainties on the location of the austral summer sea-ice edge.

An integrated view of the model-data comparison suggests that the best fit is obtained for a summer sea-ice edge situated at about $62^{\circ} \mathrm{S}$, close to the one simulated by FGOALS-G2, MRI-CGCM3 and the multi-model mean. However, as paleo records of austral summer sea-ice extent are mostly restricted to $40^{\circ}-60^{\circ} \mathrm{S}$, with $95 \%$ of the records suggesting ice-free conditions, they can only provide an estimate of the maximum summer sea-ice extent. Additional proxy records recovered from locations south of $60^{\circ} \mathrm{S}$ are thus needed to better constrain the summer sea-ice extent.

If our reconstruction of LGM summer sea-ice extent is correct, the seasonal variation of the sea-ice edge equals $\sim 10^{\circ}$ latitude, and the sea-ice extent difference equals $20 \times 10^{6} \mathrm{~km}^{2}$. In comparison, the seasonal change in sea-ice extent for present day climate equals $\sim 15 \times 10^{6} \mathrm{~km}^{2}$ (Eayrs et al., 2019), thus indicating a larger sea-ice seasonality during the LGM. Such a large sea-ice seasonality would in turn impact Southern Ocean dynamics through changes in buoyancy (Marzocchi and Jansen, 2017) as well as the carbon cycle (Haumann et al., 2016). While a large LGM sea-ice cover would contribute to the decreased atmospheric $\mathrm{CO}_{2}$ concentration (Ferrari et al., 2014), the impact of an increased sea-ice seasonality on the carbon cycle is not well constrained. The increased seasonality has potential to dampen $\mathrm{CO}_{2}$ drawdown, depending on the balance between upwelling and subsequent outgassing of carbon rich deep waters and nutrient utilization at the surface (e.g., Menviel et al., 2008). Conversely, the increased seasonality could also amplify carbon drawdown through enhanced brine formation, increasing the density gradient between the surface and deep waters (Galbraith and de Lavergne, 2019), and potentially lowering of atmospheric $\mathrm{CO}_{2}$ (Bouttes et al., 2012). Despite records showing lower productivity in the Antarctic Zone (Jaccard et al., 2013), 
https://doi.org/10.5194/cp-2020-155

Preprint. Discussion started: 22 December 2020

(c) Author(s) 2020. CC BY 4.0 License.

(c) (i)

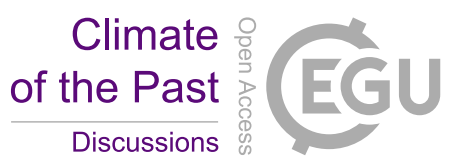

increased stratification due to sea-ice melt during spring-summer could enhance nutrient utilization and thus carbon drawdown (Sigman and Boyle, 2000; Abelmann et al., 2015).

Antarctic sea ice also integrates oceanic and atmospheric processes occurring at high southern latitudes, and as such can also significantly impact Antarctic climate (Bracegirdle et al., 2015). Sea ice has the ability to protect ice-shelves (Massom et al., 2018) and floating ice-shelves play a significant role in buttressing Antarctic outlet glaciers (Scambos et al., 2004). It is thus crucial that models incorporate a good representation of pre-industrial and present-day sea ice, but also manage to correctly simulate past sea-ice extent during both cold periods such as the LGM, and warm periods such as the Last Interglacial $(125,000$ years ago).

In that regard, it is interesting to note that the models which under-estimate austral summer Antarctic sea-ice cover at the LGM also under-estimate the austral summer sea-ice cover under pre-industrial conditions, while the model simulating the largest LGM sea-ice cover also over-estimates the pre-industrial summer sea-ice cover (Marzocchi and Jansen, 2017; Goosse et al., 2013). This implies that targeting a good agreement between model and observations for present day climate should remain a priority.

In this study, we have analysed simulated Southern Ocean winter and summer sea-ice cover in LGM simulations and evaluated the seasonality from LGM numerical simulations and evaluated the output against available proxy reconstruction data. In doing so, we identify thermal and dynamic model characteristics as potential drivers for inter-model Southern Ocean sea-ice differences, in addition to placing further constraints on the LGM austral summer and winter sea-ice extent in the Southern Ocean. This improved understanding of the relationship between model design and sea-ice dynamics can provide valuable information about the Earth system and important insight into the strengths and weaknesses of models currently used.

Data availability. LOVECLIM and multi-model mean data are available at this link: https://resdata.unsw.edu.au/pages/authenticate.faces. PMIP3 data are available at this link https://esgf-node.llnl.gov/search/cmip5/.

Author contributions. RAG performed the data analysis. LM and KJM conceived the study and provided support to the interpretation of results. XC compiled existing sea-ice proxy data and provided expert knowledge on sea-ice processes and sea-ice proxy data. RAG wrote the manuscript with contributions from LM, KJM and XC.

Competing interests. The authors declare that they have no conflict of interest.

Acknowledgements. This research is a result of the Past Global Changes (PAGES) working group 'Cycles of Sea-Ice Dynamics in the Earth system' (C-SIDE). Ryan Green was supported by a summer scholarship provided by the Australian Research Council Centre of Excellence for Climate Extremes, and UNSW (through Laurie Menviel's UNSW Scientia fellowship). Laurie Menviel and Katrin Meissner are thankful 
https://doi.org/10.5194/cp-2020-155

Preprint. Discussion started: 22 December 2020

(C) Author(s) 2020. CC BY 4.0 License.

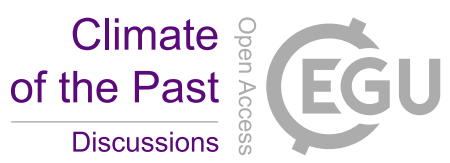

for funding from the Australian Research Council (FT180100606, DP18010004, DP180102357). Computational resources were provided by the NCI National Facility at the Australian National University, through awards under the National Computational Merit Allocation Scheme, the Intersect allocation scheme, and the UNSW HPC at NCI Scheme. 
https://doi.org/10.5194/cp-2020-155

Preprint. Discussion started: 22 December 2020

(c) Author(s) 2020. CC BY 4.0 License.

(c) (i)

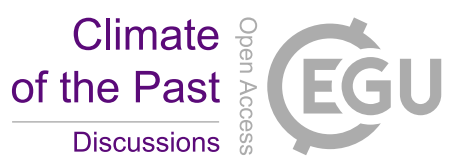

\section{References}

Abe-Ouchi, A., Saito, F., Kageyama, M., Braconnot, P., Harrison, S. P., Lambeck, K., Otto-Bliesner, B. L., Peltier, W. R., Tarasov, L., Peterschmitt, J.-Y., and Takahashi, K.: Ice-sheet configuration in the CMIP5/PMIP3 Last Glacial Maximum experiments, Geoscientific Model Development, 8, 3621-3637, https://doi.org/10.5194/gmd-8-3621-2015, https://www.geosci-model-dev.net/8/3621/2015/, 2015.

Abelmann, A., Gersonde, R., Knorr, G., Zhang, X., Chapligin, B., Maier, E., Esper, O., Friedrichsen, H., Lohmann, G., Meyer, H., et al.: The seasonal sea-ice zone in the glacial Southern Ocean as a carbon sink, Nature communications, 6, 1-13, 2015.

Allen, C., Pike, J., and Pudsey, C.: Last glacial-interglacial sea-ice cover in the SW Atlantic and its potential role in global deglaciation, Quaternary Science Reviews, 30, 2446-2458, 2011.

Bentley, M. J., Cofaigh, C., Anderson, J. B., Conway, H., Davies, B., Graham, A. G., Hillenbrand, C.-D., Hodgson, D. A., Jamieson, S. S., Larter, R. D., Mackintosh, A., Smith, J. A., Verleyen, E., Ackert, R. P., Bart, P. J., Berg, S., Brunstein, D., Canals, M., Colhoun, E. A., Crosta, X., Dickens, W. A., Domack, E., Dowdeswell, J. A., Dunbar, R., Ehrmann, W., Evans, J., Favier, V., Fink, D., Fogwill, C. J., Glasser, N. F., Gohl, K., Golledge, N. R., Goodwin, I., Gore, D. B., Greenwood, S. L., Hall, B. L., Hall, K., Hedding, D. W., Hein, A. S., Hocking, E. P., Jakobsson, M., Johnson, J. S., Jomelli, V., Jones, R. S., Klages, J. P., Kristoffersen, Y., Kuhn, G., Leventer, A., Licht, K., Lilly, K., Lindow, J., Livingstone, S. J., Massé, G., McGlone, M. S., McKay, R. M., Melles, M., Miura, H., Mulvaney, R., Nel, W., Nitsche, F. O., O’Brien, P. E., Post, A. L., Roberts, S. J., Saunders, K. M., Selkirk, P. M., Simms, A. R., Spiegel, C., Stolldorf, T. D., Sugden, D. E., van der Putten, N., van Ommen, T., Verfaillie, D., Vyverman, W., Wagner, B., White, D. A., Witus, A. E., and Zwartz, D.: A communitybased geological reconstruction of Antarctic Ice Sheet deglaciation since the Last Glacial Maximum, Quaternary Science Reviews, 100, 1 9, https://doi.org/https://doi.org/10.1016/j.quascirev.2014.06.025, http://www.sciencedirect.com/science/article/pii/S0277379114002546, reconstruction of Antarctic Ice Sheet Deglaciation (RAISED), 2014.

Benz, V., Esper, O., Gersonde, R., Lamy, F., and Tiedemann, R.: Last Glacial Maximum sea surface temperature and sea-ice extent in the Pacific sector of the Southern Ocean, Quaternary Science Reviews, 146, 216-237, 2016.

Bouttes, N., Roche, D., and Paillard, D.: Systematic study of the impact of fresh water fluxes on the glacial carbon cycle, Climate of the Past, 8, 589-607, 2012.

Bracegirdle, T. J., Stephenson, D. B., Turner, J., and Phillips, T.: The importance of sea ice area biases in 21 st century multimodel projections of Antarctic temperature and precipitation, Geophysical Research Letters, 42, 10-832, 2015.

Brady, E. C., Otto-Bliesner, B. L., Kay, J. E., and Rosenbloom, N.: Sensitivity to glacial forcing in the CCSM4, Journal of Climate, 26, 1901-1925, 2013.

Carlson, A. and Winsor, K.: Northern Hemisphere ice-sheet responses to past climate warming, Nature Geoscience, 5, 507 -613, https://doi.org/10.1038/ngeo1528, 2012.

Cavalieri, D. J. and Parkinson, C. L.: Arctic sea ice variability and trends, 1979-2010, The Cryosphere, 6, 881, 2012.

Clark, P. U., Dyke, A. S., Shakun, J. D., Carlson, A. E., Clark, J., Wohlfarth, B., Mitrovica, J. X., Hostetler, S. W., and McCabe, A. M.: The last glacial maximum, science, 325, 710-714, 2009.

CLIMAP-Project-Members: Map and Chart Ser. MC-36, chap. Seasonal reconstruction of the Earth surface at the last glacial maximum, Lamont-Doherty Geological Observatory of Columbia University, Palisades, 1981.

Crosta, X., Pichon, J., and Burckle, L.: Application of modern analog technique to marine Antarctic diatoms: Reconstruction of maximum sea-ice extent at the Last Glacial Maximum, Paleoceanography, 13, 284-297, 1998. 
https://doi.org/10.5194/cp-2020-155

Preprint. Discussion started: 22 December 2020

(c) Author(s) 2020. CC BY 4.0 License.

(c) (i)

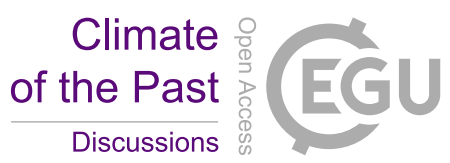

Doddridge, E. W. and Marshall, J.: Modulation of the seasonal cycle of Antarctic sea ice extent related to the Southern Annular Mode, Geophysical Research Letters, 44, 9761-9768, 2017.

Dufresne, J.-L., Foujols, M.-A., Denvil, S., Caubel, A., Marti, O., Aumont, O., Balkanski, Y., Bekki, S., Bellenger, H., Benshila, R., et al.: Climate change projections using the IPSL-CM5 Earth System Model: from CMIP3 to CMIP5, Climate dynamics, 40, $2123-2165,2013$.

Eayrs, C., Holland, D., Francis, D., Wagner, T., Kumar, R., and Li, X.: Understanding the Seasonal Cycle of Antarctic Sea Ice Extent in the Context of Longer-Term Variability, Reviews of Geophysics, 57, 1037-1064, 2019.

Elderfield, H., Greaves, M., Barker, S., Hall, I. R., Tripati, A., Ferretti, P., Crowhurst, S., Booth, L., and Daunt, C.: A record of bottom water temperature and seawater $\delta 180$ for the Southern Ocean over the past $440 \mathrm{kyr}$ based on $\mathrm{Mg} / \mathrm{Ca}$ of benthic foraminiferal Uvigerina spp., Quaternary Science Reviews, 29, 160-169, 2010.

Esper, O. and Gersonde, R.: Quaternary surface water temperature estimations: New diatom transfer functions for the Southern Ocean, Palaeogeography, Palaeoclimatology, Palaeoecology, 414, 1-19, 2014a.

Esper, O., Gersonde, R., and Lohmann, G.: Southern Ocean surface temperature and sea ice fields during the Last Interglacial, AGUFM, 2014b, PP21G-06, 2014b.

Ferrari, R., Jansen, M. F., Adkins, J. F., Burke, A., Stewart, A. L., and Thompson, A. F.: Antarctic sea ice control on ocean circulation in present and glacial climates, Proceedings of the National Academy of Sciences, 111, 8753-8758, 2014.

Ferry, A. J., Crosta, X., Quilty, P. G., Fink, D., Howard, W., and Armand, L. K.: First records of winter sea ice concentration in the southwest Pacific sector of the Southern Ocean, Paleoceanography, 30, 1525-1539, 2015.

Frölicher, T. L., Sarmiento, J. L., Paynter, D. J., Dunne, J. P., Krasting, J. P., and Winton, M.: Dominance of the Southern Ocean in anthropogenic carbon and heat uptake in CMIP5 models, Journal of Climate, 28, 862-886, 2015.

Galbraith, E. and de Lavergne, C.: Response of a comprehensive climate model to a broad range of external forcings: relevance for deep ocean ventilation and the development of late Cenozoic ice ages, Climate Dynamics, 52, 653-679, 2019.

Gent, P. R., Danabasoglu, G., Donner, L. J., Holland, M. M., Hunke, E. C., Jayne, S. R., Lawrence, D. M., Neale, R. B., Rasch, P. J., Vertenstein, M., et al.: The community climate system model version 4, Journal of climate, 24, 4973-4991, 2011

Gersonde, R., Crosta, X., Abelmann, A., and Armand, L.: Sea-surface temperature and sea ice distribution of the Southern Ocean at the EPILOG Last Glacial Maximum - A circum-Antarctic view based on siliceous microfossil records, Quaternary Science Reviews, 24, 869-896, 2005.

Ghadi, P., Nair, A., Crosta, X., Mohan, R., Manoj, M., and Meloth, T.: Antarctic sea-ice and palaeoproductivity variation over the last 156,000 years in the Indian sector of Southern Ocean, Marine Micropaleontology, 160, 101 894, 2020.

Giorgetta, M. A., Jungclaus, J., Reick, C. H., Legutke, S., Bader, J., Böttinger, M., Brovkin, V., Crueger, T., Esch, M., Fieg, K., et al.: Climate and carbon cycle changes from 1850 to 2100 in MPI-ESM simulations for the Coupled Model Intercomparison Project phase 5, Journal of Advances in Modeling Earth Systems, 5, 572-597, 2013.

Goosse, H., Brovkin, V., Fichefet, T., Jongma, J., Huybrechts, P., Mouchet, A., Barriat, P.-Y., Campin, J.-M., Deleersnijder, E., Driesschaert, E., Goelzer, H., Haarsma, R., Janssens, Y., Loutre, M.-F., Maqueda, M. A. M., Opsteegh, T., Mathieu, P.-P., Munhoven, G., Petterson, E., Renssen, H., Roche, D., Schaeffer, M., Selten, F., Severijns, C., Tartinville, B., and Weber, N.: Description of the Earth system model of intermediate complexity LOVECLIM version 1.2., Geoscientific Model Development, 3, 603-633, 2010.

Goosse, H., Roche, D., Mairesse, A., and Berger, M.: Modelling past sea ice changes, Quaternary Science Reviews, 79, 191-206, 2013.

Haumann, F. A., Gruber, N., Münnich, M., Frenger, I., and Kern, S.: Sea-ice transport driving Southern Ocean salinity and its recent trends, Nature, 537, 89-92, 2016. 
https://doi.org/10.5194/cp-2020-155

Preprint. Discussion started: 22 December 2020

(c) Author(s) 2020. CC BY 4.0 License.

(c) (i)

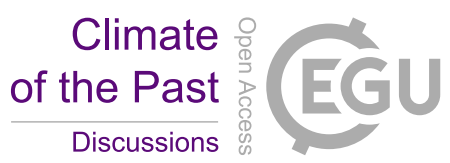

Holland, P. R. and Kwok, R.: Wind-driven trends in Antarctic sea-ice drift, Nature Geoscience, 5, 872-875, 2012.

Howe, J., Piotrowski, A., Noble, T., Mulitza, S., Chiessi, C., and Bayon, G.: North Atlantic Deep Water Production during the Last Glacial Maximum, Nature Communications, 7, doi:10.1038/ncomms11 765, 2016.

Jaccard, S. L., Hayes, C. T., Martinez-Garcia, A., Hodell, D. A., Anderson, R. F., Sigman, D. M., and Haug, G.: Two modes of change in

Southern Ocean productivity over the past million years, Science, 339, 1419-1423, 2013.

Kageyama, M., Braconnot, P., Bopp, L., Caubel, A., Foujols, M.-A., Guilyardi, E., Khodri, M., Lloyd, J., Lombard, F., Mariotti, V., et al.: Mid-Holocene and Last Glacial Maximum climate simulations with the IPSL model-Part I: Comparing IPSL_CM5A to IPSL_CM4, Climate dynamics, 40, 2447-2468, 2013.

Kageyama, M., Albani, S., Braconnot, P., Harrison, S. P., Hopcroft, P. O., Ivanovic, R. F., Lambert, F., Marti, O., Pe ltier, W. R., Peterschmitt, J.-Y., Roche, D. M., Tarasov, L., Zhang, X., Brady, E. C., Haywood, A. M., LeGrande, A. N., Lunt, D. J., Mahowald, N. M., Mikolajewicz, U., Nisancioglu, K. H., Otto-Bliesner, B. L., Renssen, H., Tomas, R. A., Zhang, Q., Abe-Ouch i, A., Bartlein, P. J., Cao, J., Li, Q., Lohmann, G., Ohgaito, R., Shi, X., Volodin, E., Yoshida, K., Zhang, X., and Zheng, W.: The PMIP4 contribution to CMIP6 - Part 4: Scientific objectives and experimental design of the PMIP4-CMIP6 Last Glacial Maximum experiments and PMIP4 sensitivity experiments, Geoscientific Model Development, 10, 4035-4055, https://doi.org/10.5194/gmd-10-4035-2017, https://www.geosci-model-dev.net/10/4035/2017/, 2017.

Kageyama, M., Harrison, S. P., Kapsch, M.-L., Löfverström, M., Lora, J. M., Mikolajewicz, U., Sherriff-Tadano, S., Vadsaria, T., Abe-Ouchi, A., Bouttes, N., Chandan, D., LeGrande, A. N., Lhardy, F., Lohmann, G., Morozova, P. A., Ohgaito, R., Peltier, W. R., Quiquet, A., Roche, D. M., Shi, X., Schmittner, A., Tierney, J. E., and Volodin, E.: The PMIP4-CMIP6 Last Glacial Maximum experiments: preliminary results and comparison with the PMIP3-CMIP5 simulations, Climate of the Past Discussions, 2020, 1-37, https://doi.org/10.5194/cp-2019-169, https://www.clim-past-discuss.net/cp-2019-169/, 2020.

Klockmann, M., Mikolajewicz, U., and Marotzke, J.: The effect of greenhouse gas concentrations and ice sheets on the glacial AMOC in a coupled climate model, Climate of the Past, 12, 1829-1846, 2016.

Kohfeld, K., Graham, R., de Boer, A., Sime, L., Wolff, E., Qur, C. L., and Bopp, L.: Southern Hemisphere westerly wind changes during the Last Glacial Maximum: paleo-data synthesis, Quaternary Science Reviews, 68, 76-95, https://doi.org/https://doi.org/10.1016/j.quascirev.2013.01.017, 2013.

Kohfeld, K. E. and Chase, Z.: Temporal evolution of mechanisms controlling ocean carbon uptake during the last glacial cycle, Earth and Planetary Science Letters, 472, 206-215, 2017.

Landschützer, P., Gruber, N., Haumann, F. A., Rödenbeck, C., Bakker, D. C. E., van Heuven, S., Hoppema, M., Metzl, N., Sweeney, C., Takahashi, T., Tilbrook, B., and Wanninkhof, R.: The reinvigoration of the Southern Ocean carbon sink, Science, 349, 1221-1224, https://doi.org/10.1126/science.aab2620, http://science.sciencemag.org/content/349/6253/1221, 2015.

Li, L., Lin, P., Yu, Y., Wang, B., Zhou, T., Liu, L., Liu, J., Bao, Q., Xu, S., Huang, W., et al.: The flexible global ocean-atmosphere-land system model, grid-point version 2: FGOALS-g2, Advances in Atmospheric Sciences, 30, 543-560, 2013.

Locarnini, R., Mishonov, A., Antonov, J., Boyer, T., Garcia, H., Baranova, O., Zweng, M., and Johnson, D.: NOAA Atlas NESDIS 68 WORLD OCEAN ATLAS 2009, vol. 1: Temperature, Tech. rep., technical report march, US Gov. Print. Off., Washington, DC, 2010.

Lynch-Stieglitz, J., Adkins, J. F., Curry, W. B., Dokken, T., Hall, I. R., Herguera, J. C., Hirschi, J. J.-M., Ivanova, E. V., Kissel, C., Marchal, O., et al.: Atlantic meridional overturning circulation during the Last Glacial Maximum, science, 316, 66-69, 2007. 
https://doi.org/10.5194/cp-2020-155

Preprint. Discussion started: 22 December 2020

(c) Author(s) 2020. CC BY 4.0 License.

(c) (i)

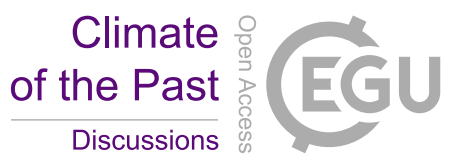

Marcott, S., Bauska, T., Buizert, C., Steig, E., Rosen, J., Cuffey, K., Fudge, T., Severinghaus, J., Ahn, J., Kalk, M., McConnell, J., Sowers,

T., Taylor, K., White, J., and Brook, E.: Centennial-scale changes in the global carbon cycle during the last deglaciation, Nature, 514, 616-619, https://doi.org/10.1038/nature13799, 2014.

Marzocchi, A. and Jansen, M. F.: Connecting Antarctic sea ice to deep?ocean circulation in modern and glacial climate simulations, Geophysical Research Letters, 44, 6286-6295, https://doi.org/10.1002/2017GL073936, 2017.

Massom, R., Scambos, T., Bennetts, L., Reid, P., Squire, V., and Stammerjohn, S.: Antarctic ice shelf disintegration triggered by sea ice loss and ocean swell, Nature, 558, 383-389, https://doi.org/10.1038/s41586-018-0212-1, 2018.

Mayewski, P., Carleton, A., Birkel, S., Dixon, D., Kurbatov, A., Korotkikh, E., McConnell, J., Curran, M., Cole-Dai, J., Jiang, S., et al.: Ice core and climate reanalysis analogs to predict Antarctic and Southern Hemisphere climate changes, Quaternary Science Reviews, 155, 50-66, 2017.

Meijers, A.: The Southern Ocean in the coupled model intercomparison project phase 5, Philosophical Transactions of the Royal Society A: Mathematical, Physical and Engineering Sciences, 372, 20130 296, 2014.

Menviel, L., Timmermann, A., Mouchet, A., and Timm, O.: Climate and marine carbon cycle response to changes in the strength of the southern hemispheric westerlies, Paleoceanography, 23, doi:10.1029/2007PA001 604, 2008.

Menviel, L., Yu, J., Joos, F., Mouchet, A., Meissner, K., and England, M.: Poorly ventilated deep ocean at the Last Glacial Maximum inferred from carbon isotopes: a data-model comparison study, Paleoceanography, 32, 2-17, https://doi.org/10.1002/2016PA003024, 2017.

Mikaloff-Fletcher, S., Gruber, N., Jacobson, A., Doney, S., Dutkiewicz, S., Gerber, M., Follows, M., Joos, F., Lindsay, K., Menemenlis, D., Mouchet, A., Müller, S., and Sarmiento, J.: Inverse estimates of anthropogenic $\mathrm{CO}_{2}$ uptake, tranport, and storage by the ocean, Global Biogeochemical Cycles, 20, GB2002, https://doi.org/10.1029/2005GB002530, 2006.

Muglia, J. and Schmittner, A.: Glacial Atlantic overturning increased by wind stress in climate models, Geophysical Research Letters, 42, 9862-9868, https://doi.org/10.1002/2015GL064583, https://agupubs.onlinelibrary.wiley.com/doi/abs/10.1002/2015GL064583, 2015.

Nair, A., Mohan, R., Crosta, X., Manoj, M., Thamban, M., and Marieu, V.: Southern Ocean sea ice and frontal changes during the Late Quaternary and their linkages to Asian summer monsoon, Quaternary Science Reviews, 213, 93-104, 2019.

Parkinson, C. L.: A 40-y record reveals gradual Antarctic sea ice increases followed by decreases at rates far exceeding the rates seen in the Arctic, Proceedings of the National Academy of Sciences, 116, 14414-14423, https://doi.org/10.1073/pnas.1906556116, https: //www.pnas.org/content/116/29/14414, 2019.

Purich, A., Cai, W., England, M., and Cowan, T.: Evidence for link between modelled trends in Antarctic sea ice and underestimated westerly wind changes, Nature Communications, 7, 10409 , https://doi.org/10.1038/ncomms10409, 2016

Roche, D., Crosta, X., and Renssen, H.: Evaluating Southern Ocean sea-ice for the Last Glacial Maximum and pre-industrial climates: PMIP-2 models and data evidence, Quaternary Science Reviews, 56, 99-106, 2012.

Sabine, C., Feely, R., Gruber, N., Key, R., Lee, K., Bullister, J., Wanninkhof, R., Wong, C., Wallace, D., Tilbrook, B., Millero, F., Peng, T.-H., Kozyr, A., Ono, T., and Rios, A.: The oceanic sink of anthropogenic $\mathrm{CO}_{2}$, Science, 305, 367-371, 2004.

Scambos, T. A., Bohlander, J., Shuman, C. A., and Skvarca, P.: Glacier acceleration and thinning after ice shelf collapse in the Larsen B embayment, Antarctica, Geophysical Research Letters, 31, 2004.

Schmidt, G. A., Jungclaus, J. H., Ammann, C. M., Bard, E., Braconnot, P., Crowley, T. J., Delaygue, G., Joos, F., Krivova, N. A., Muscheler, R., Otto-Bliesner, B. L., Pongratz, J., Shindell, D. T., Solanki, S. K., Steinhilber, F., and Vieira, L. E. A.: Climate forcing reconstructions for use in PMIP simulations of the last millennium (v1.0), Geosci. Model Dev., 4, 33-45, https://doi.org/10.5194/gmd-4-33-2011, 2011. 
https://doi.org/10.5194/cp-2020-155

Preprint. Discussion started: 22 December 2020

(c) Author(s) 2020. CC BY 4.0 License.

(c) (i)

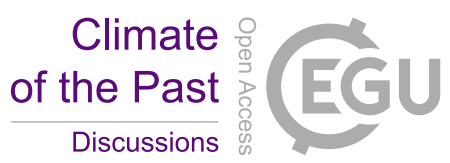

Schmidt, G. A., Kelley, M., Nazarenko, L., Ruedy, R., Russell, G. L., Aleinov, I., Bauer, M., Bauer, S. E., Bhat, M. K., Bleck, R., et al.:

Configuration and assessment of the GISS ModelE2 contributions to the CMIP5 archive, Journal of Advances in Modeling Earth Systems, 6, 141-184, 2014.

Schulzweida, U., Kornblueh, L., and Quast, R.: CDO: Climate Data Operators v1. 6.4, Cent. Mar. Atmos. Sci..(ZMAW). Max-Planck Inst. Meteorol. Univ. Hamburg. https://code. zmaw. de/projects/cdo (last access August 2014), 2014.

Schweitzer, P. N.: Monthly average polar sea-ice concentration: US Geological Survey digital data series DDS-27, US Geological Survey,

Reston, Virginia. Dataset information available online at http://pubs. usgs. gov/dds/dds27, 1995.

Sigman, D. and Boyle, E.: Glacial/interglacial variations in atmospheric carbon dioxide, Nature, 407, 859-869, 2000.

Sime, L. C., Hodgson, D., Bracegirdle, T. J., Allen, C., Perren, B., Roberts, S., and de Boer, A. M.: Sea ice led to poleward-shifted winds at the Last Glacial Maximum: the influence of state dependency on CMIP5 and PMIP3 models, Climate of the Past, 12, 2241-2253, https://doi.org/10.5194/cp-12-2241-2016, https://www.clim-past.net/12/2241/2016/, 2016.

Skinner, L., Primeau, F., Freeman, E., de la Fuente, M., Goodwin, P., Gottschalk, J., Huang, E., McCave, I., Noble, T., and Scrivner, A.: Radiocarbon constraints on the glacial ocean circulation and its impact on atmospheric $\mathrm{CO}_{2}$, Nature Communications, 8,16010 , https://doi.org/10.1038/ncomms16010, 2017.

Sueyoshi, T., Ohgaito, R., Yamamoto, A., Chikamoto, M., Hajima, T., Okajima, H., Yoshimori, M., Abe, M., O’ishi, R., Saito, F., et al.: Setup of the PMIP3 paleoclimate experiments conducted using an Earth system model, MIROC-ESM, Geoscientific Model Development, 6, 819-836, 2013.

Voldoire, A., Sanchez-Gomez, E., y Mélia, D. S., Decharme, B., Cassou, C., Sénési, S., Valcke, S., Beau, I., Alias, A., Chevallier, M., et al.: The CNRM-CM5. 1 global climate model: description and basic evaluation, Climate dynamics, 40, 2091-2121, 2013.

Waelbroeck, C., Paul, A., Kucera, M., Rosell-Melé, A., Weinelt, M., Schneider, R., Mix, A., Abelmann, A., Armand, L., Bard, E., Barker, S., Barrows, T., Benway, H., Cacho, I., Chen, M., Cortijo, E., Crosta, X., de Vernal, A., Dokken, T., Duprat, J., Elderfield, H., Eynaud, F., Gersonde, G., Hayes, A., Henry, M., Hillaire-Marcel, C., Huang, C., Jansen, E., Juggins, S., Kallel, N., Kiefer, T., Kienast, M., Labeyrie, L., Leclaire, H., Londeix, L., Mangin, S., Matthiessen, J., Marret, F., Meland, M., Morey, A., Mulitza, S., Pflaumann, U., Pisias, N., Radi, T., Rochon, A., Rohling, E., Sbaffi, L., Schaefer-Neth, C., Solignac, S., Spero, H., Tachikawa, K., Turon, J., and project members, M.: Constraints on the magnitude and patterns of ocean cooling at the Last Glacial Maximum, Nature Geoscience, 2, 127-132, 2009.

Wang, G., Hendon, H. H., Arblaster, J. M., Lim, E.-P., Abhik, S., and van Rensch, P.: Compounding tropical and stratospheric forcing of the record low Antarctic sea-ice in 2016, Nature communications, 10, 1-9, 2019.

Watanabe, M., Chikira, M., Imada, Y., and Kimoto, M.: Convective control of ENSO simulated in MIROC, Journal of Climate, 24, 543-562, 2011.

Xiao, W., Esper, O., and Gersonde, R.: Last Glacial-Holocene climate variability in the Atlantic sector of the Southern Ocean, Quaternary Science Reviews, 135, 115-137, 2016.

Yukimoto, S., Adachi, Y., Hosaka, M., Sakami, T., Yoshimura, H., Hirabara, M., Tanaka, T. Y., Shindo, E., Tsujino, H., Deushi, M., et al.: A new global climate model of the Meteorological Research Institute: MRI-CGCM3-Model description and basic performance-, Journal of the Meteorological Society of Japan. Ser. II, 90, 23-64, 2012.

Zheng, F., Li, J., Clark, R., and Nnamchi, H.: Simulation and Projection of the Southern Hemisphere Annular Mode in CMIP5 Models, Journal of Climate, 26, 9860-9879, https://doi.org/10.1175/JCLI-D-13-00204.1, 2013.

535 Zheng, W. and Yu, Y.: Paleoclimate simulations of the mid-Holocene and Last Glacial Maximum by FGOALS, Advances in Atmospheric Sciences, 30, 684-698, 2013. 